\title{
İncirli Köyü Martyrium Mozaikleri ve Hatay Mozaikleri Arasındaki Yeri
}

\section{İncirli Village Martyrium Mosaics and the Place of These Mosaics in Hatay Mosaics}

Ömer ÇELİK*

(Received 25 July 2020, accepted after revision 27 August 2021)

\begin{abstract}
Öz
İncirli Köyü Martyrium Mozaikleri, Hatay İli, Kırıkhan İlçesi, İncirli Köyünde’dir. Martyrium da üç mekân tespit edilmiştir. Plan vermeyen mimari, düzensiz dere taşları ve kalker bloklarla yapılmıştır. Mekânlarda açı̆̆a çıkarılan mozaikler üç panodan meydana gelmişsir. Hatay genelinde kilise, bazilika veya martyrium kazılarında ortaya çıkarılan mozaiklerde cennet tasvirli konular sık işlendiği gibi dini olaylar, portreler, hayvan, bitki ve geometrik motifler de işlenmiştir. Hatay'da çıkarılan mozaiklerin kompozisyonlarının İncirli Köyü Martyrium Mozaikleri ile benzer yanları olduğu gibi farklllıkları da bulunmaktadır. Hatay'da bulunan sivil ve dini mekânlarda yapılan mozaik döşemelerindeki konu, kompozisyon, figür, motif ve bordürler incelendiğinde, is 2. yüzyllda başlayan sanatsal süreç, Antakya'da bulunan diğer Doğu Roma mozaiklerinde ifade edildiği gibi Incirli Köyü Martyrium Mozaiği'nde de IS 6. yüzylla kadar izlenmektedir.
\end{abstract}

Anahtar Kelimeler: Antakya, Incirli, mozaik, martyrium.

\begin{abstract}
Incirli Martyrium Mosaics were found in the village of Incirli at Kirlkhan, Hatay. Three room spaces are defined in the martyrium. Riverbed stones and calcareous blocks were used in the architecture, although its plan is incomplete. The mosaics found in the rooms are composed of three panels. In the Hatay region, mosaics found in church, basilica or martyrium contexts are generally depicting scenes of heaven as well as religious events, portraits, animals, plants and geometric motifs. Hatay mosaics share similarities and differences in composition to Incirli Village Martyrium Mosaics. When the subjects, composition, figures, motifs and borders of the mosaic floors made in civil and religious building in Hatay are examined, the artistic process that started in the $2^{\text {nd }}$ century $A D$ is expressed in the other Eastern Roman mosaics in Antakya, as well as in the Incirli Village Martyrium Mosaics. It is traced back to the $6^{\text {th }}$ century $A D$.
\end{abstract}

Keywords: Antioch, Incirli, mosaic, martyrium.

\footnotetext{
* Ömer Çelik, Arkeolog, Hatay Arkeoloji Müzesi, Hatay, Türkiye. 
İncirli Köyü Martyrium Mozaiği, Hatay İli, Kırıkhan İlçesi, İncirli Köyü’nde Hatay Müze Müdürlügü tarafından 08.04.1996 tarihinde tespit edilmiştir. İncirli Köyü, Hatay İli'nin 40 km doğusunda bulunan Kırıkhan İlçesi'ne yaklaşık 25 km mesafededir. Köy, Kurt Dağları'nın eteklerinde kurulmuş, Amik Ovası'na hâkim, Suriye sınırına yakın bir noktadadır (Res. 1).

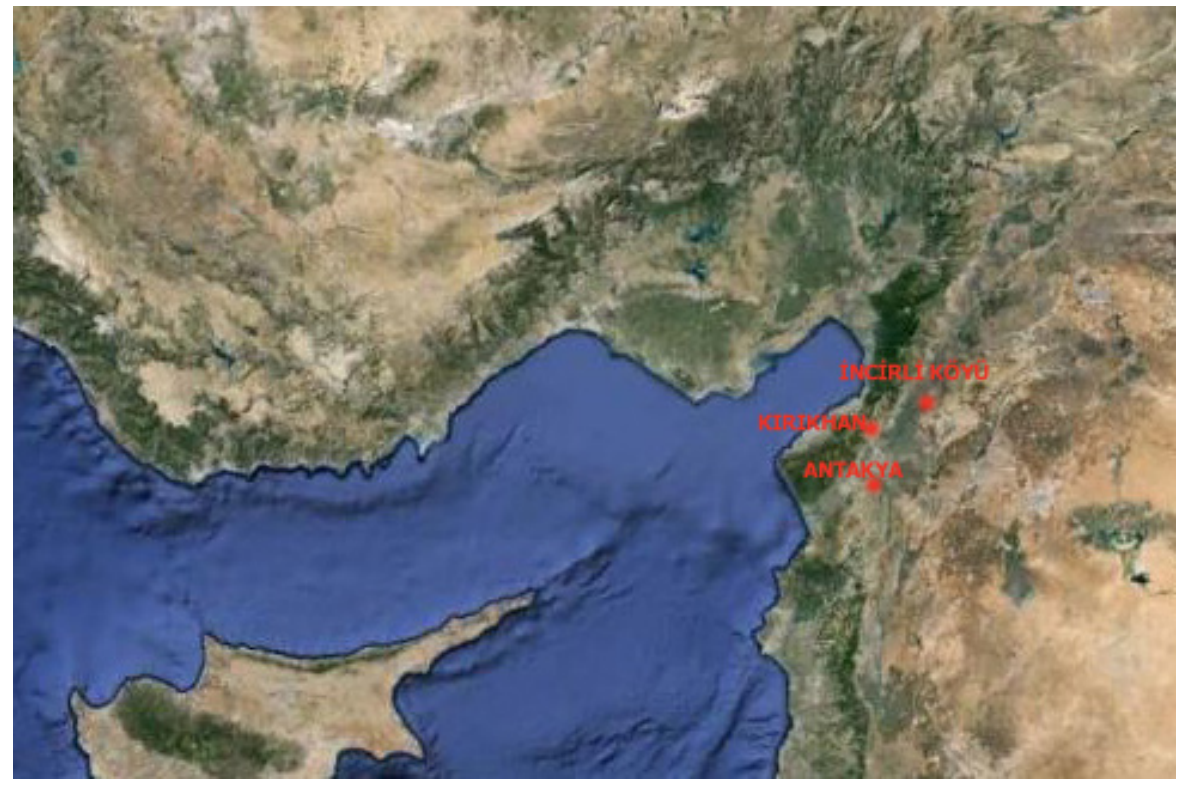

2007 yılında Müze Müdürlüğü Başkanlığında aynı köyde Martyriumun dışında farklı parselde bulunan kilisede kurtarma kazısı (Çelik 2013: 1) gerçekleştirilmiştir. Her iki dini yapıda mozaik tabanlar bulunmuştur. Kilise, mozaiklerden yola çıkarak İS V. - VI. yüzyıla tarihlendirilmekte, Martyrium ise Grekçe kitabesinde tarih verildiği için İS VI. yüzyıla tarihlendirilmiştir. İki dini yapının aynı dönemler içerisinde varlığını sürdürdüğü düşünülebilir fakat İncirli Köyü'nde ortaya çıkarılan iki dini yapının yakın tarihler içerisinde varlığını sürdürmesi ve aynı köyde bulunmasının dışında arasında tam olarak bir ilişki kurulamamıştır.

Hatay Müze Müdürlüğü başkanlığında, 2007 yılında yapılan kurtarma kazısı (Çelik 2013: 1), Arkeolog Ömer ÇELİK tarafından yapılmıştır. Kazı, köy evinin bahçesinde ve etrafi konutlarla çevrili dar bir alanda gerçekleştirilmiştir (Res. 2). Kazı alanı günümüz yapıları ile çevrili olması sebebiyle mimari tam olarak açığa çıkarılamamıştır. Plan vermeyen mimari, düzensiz dere taşları ve kalker bloklarla yapılmıştır (Res. 3). Üç mekân tespit edilmiştir (Res. 3, Çiz. 1). Güneyde kesme blok taşlarla yapılan zemini pişmiş toprak levha ile kaplı I. mekân yer almaktadır (Res. 4). II. mekân orta bölümde kısmen dikdörtgen şekle benzer bir yapıya sahip olup tam plan vermemektedir (Res. 5). II. mekânın zemini mozaik döşelidir. III. mekân ise kuzeyde olup bu mekânda plan vermemektedir (Res. 6). Bu mekânın zemini de mozaik döşelidir (Çiz. 2 - 3). II. mekânda ortaya çıkarılan mozaikteki yazıtta, yapının "martyrium" olduğu belirtildiği için işlevi anlaşılmıştır. Tespit edilen martyrium mozaiklerinin büyük bölümü tahrip olmuştur. Açığa çıkarılan mozaikler üç panodan meydana gelmiştir (Çiz. 2).

İncirli Köyü Martyrium Mozaiklerinde 10 hayvan figürü, 4 bitki motifi işlenmiştir. Teseraların en ve boyları $0,6 \mathrm{~cm}-1,2 \mathrm{~cm}$ arasında, yükseklikleri 0,5 $\mathrm{cm}-1 \mathrm{~cm}$ arasında değişmektedir (Res. 7).
Resim 1

Hatay İli, Kırıkhan İlçesi, İncirli Köyü. 




Resim 2

Kazı alanı ve çevresi.

Resim 3

Üç mekânı açığa çıkarılan Matriyon, mimaride kullanılan kalker bloklar ve düzensiz dere taşları.

Resim 4

I numaralı mekân.


Resim 5

II numaralı mekân. 

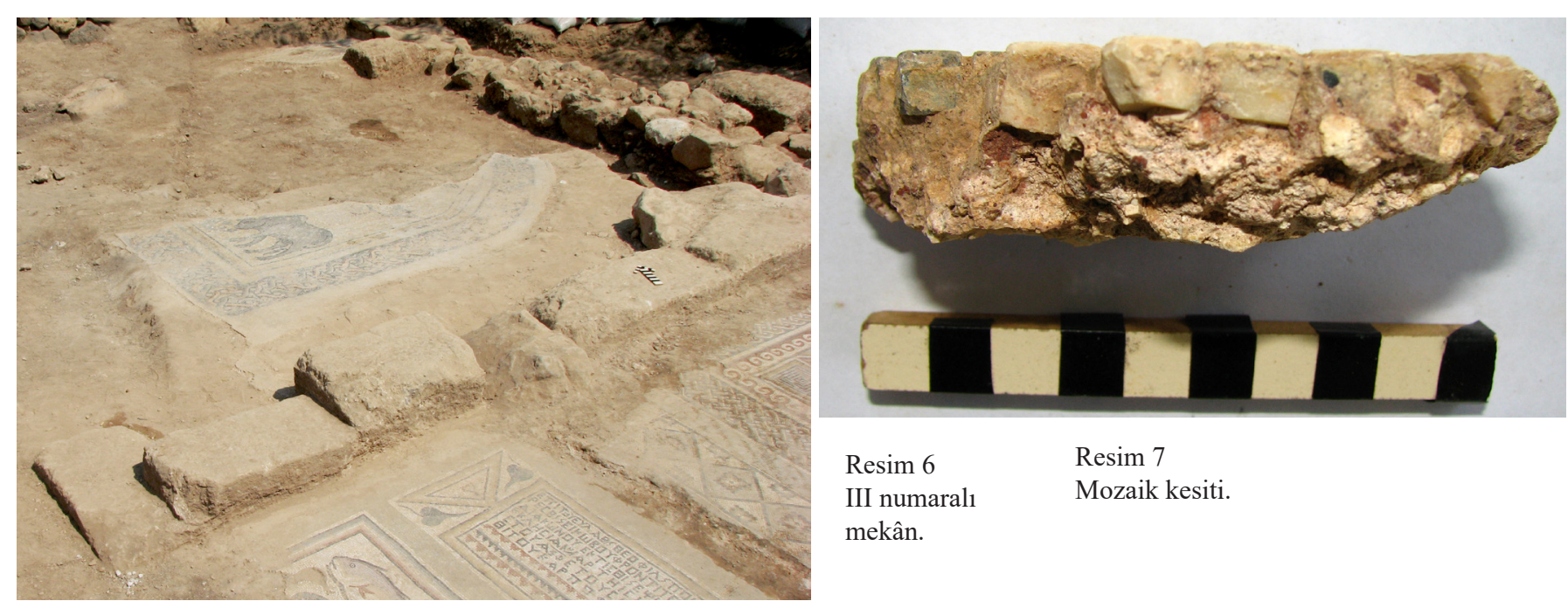

mekân.


Mozaiklerde siyah, beyaz, kirli beyaz, çamurlaşmış yeşil, uçuk kahverengi, koyu kahverengi, kızıl kahverengi, kızıl kırmızı, açık gri, koyu gri, lila ve oksit sarı olmak üzere 12 renk kullanılmıştır.

II ve III numaralı mekânlarda ortaya çıkan taban mozaiği üç ana panodan oluşmuştur (Çiz. 2 - 3).

\section{Pano}

I. pano dört bölümden (Res. 8) meydana gelmiştir. Birinci bölüm kitabe (Res. 9, Çiz. 4), ikinci bölüm geometrik motifler ve kuş figürleri (Res. 10, Çiz. 4),

\section{Açığa çıkarılan üç mekân.}

Çizim 2 - 3

Mozaiklerin mimarideki yerleri.

Çizim 1 


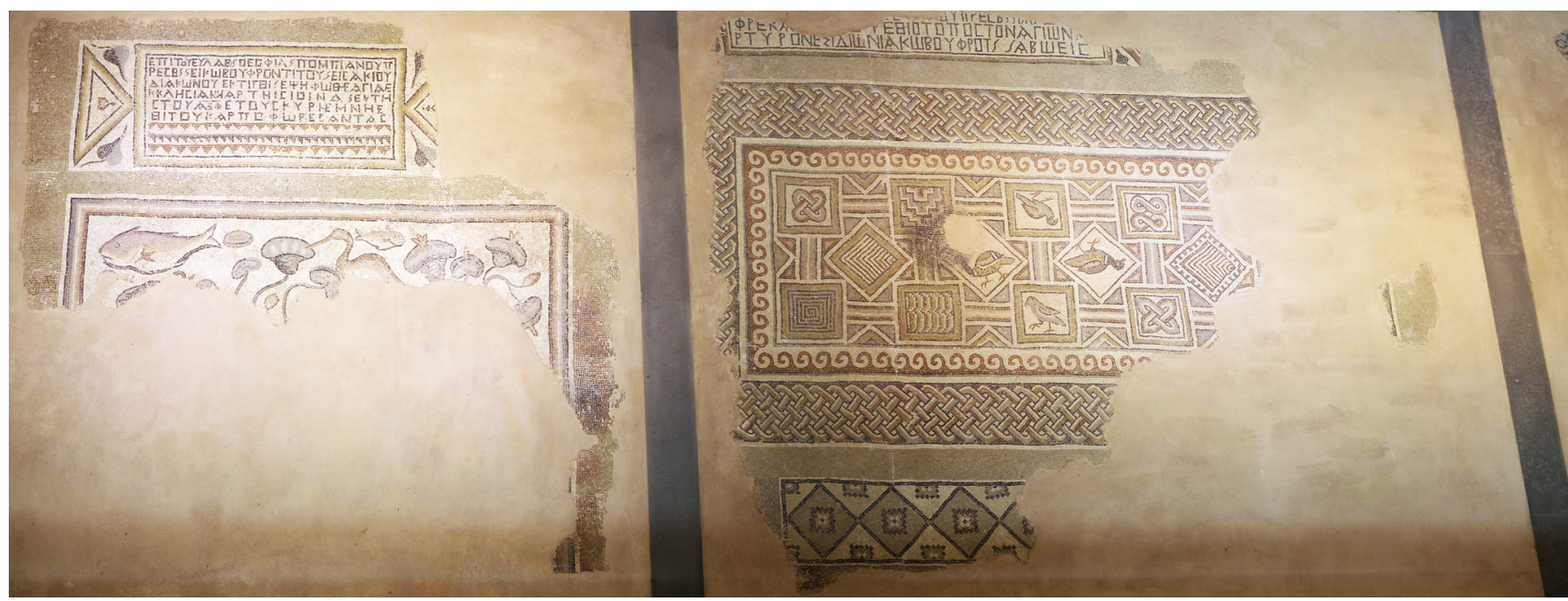

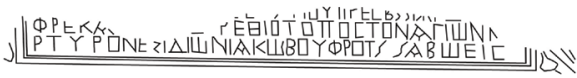
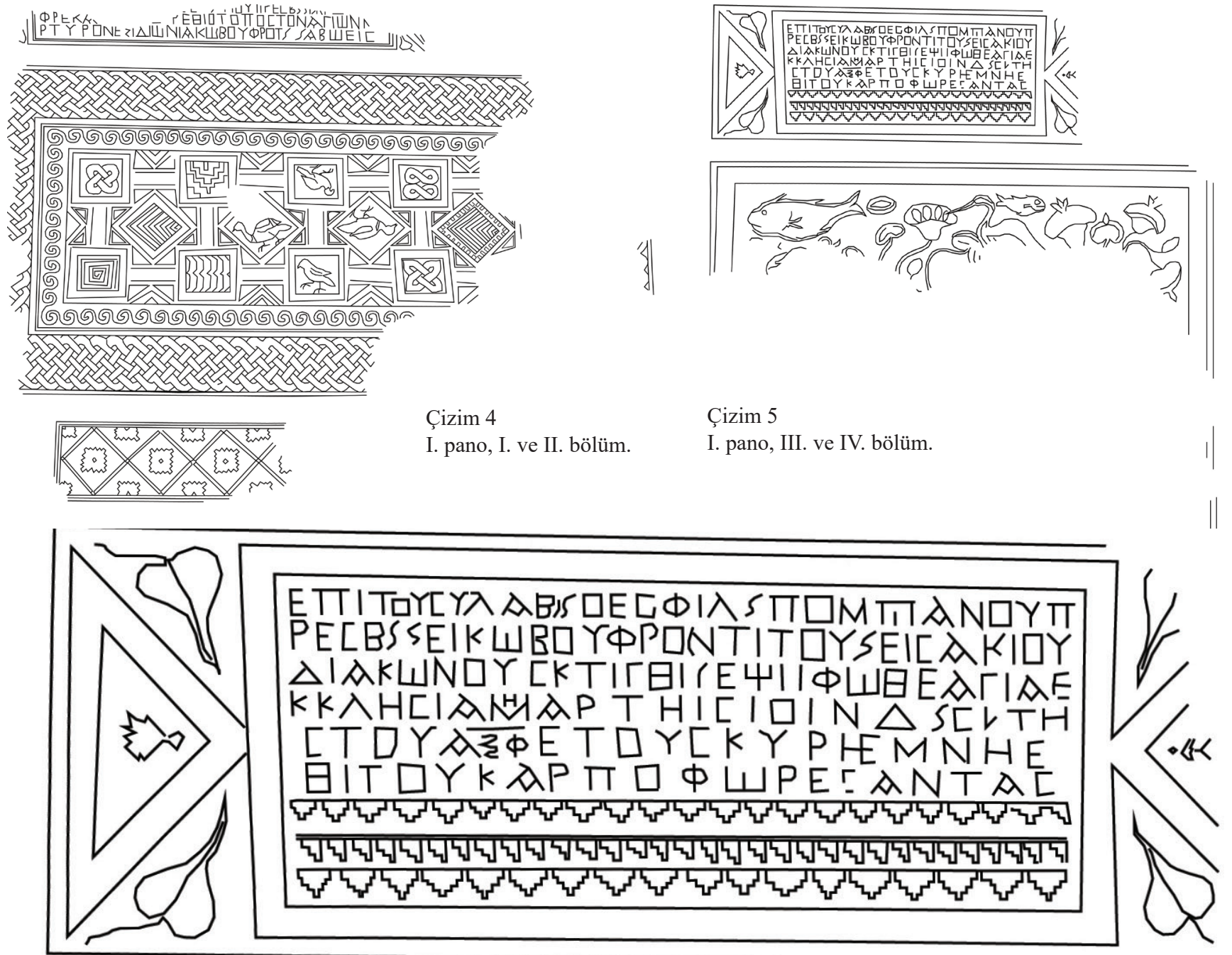

Çizim 6

I. pano, III. bölüm. 


\section{Bölüm}

I. panonun doğu bölümünde tahrip olmuş 3 sıra Grekçe yazı bulunmaktadır. Yaklaşık $3 \mathrm{~m}$ uzunluğundaki yazıt, beyaz zemin üzerine siyah renk tesseralarla işlenmiş siyah bir çizgi (Décor I: pl.1) ve kalın siyah, beyaz, çamurlaşmış yeşil ve uçuk kahverengi asimetrik bant (Décor I: pl.36c) ile sınırlandırılmıştır. Kitabenin solunda siyah tesseralarla işlenmiş yaprak motifi ve çerçevenin bir parçası bulunmaktadır. Kitabe ve merkez pano arasına açık gri tesseralarla işlenmiş tek renkli bant (Décor I: pl.1y) yerleştirilmiştir (Res. 9, Çiz. 4).
Resim 9

I. pano, I. bölüm kitabe.

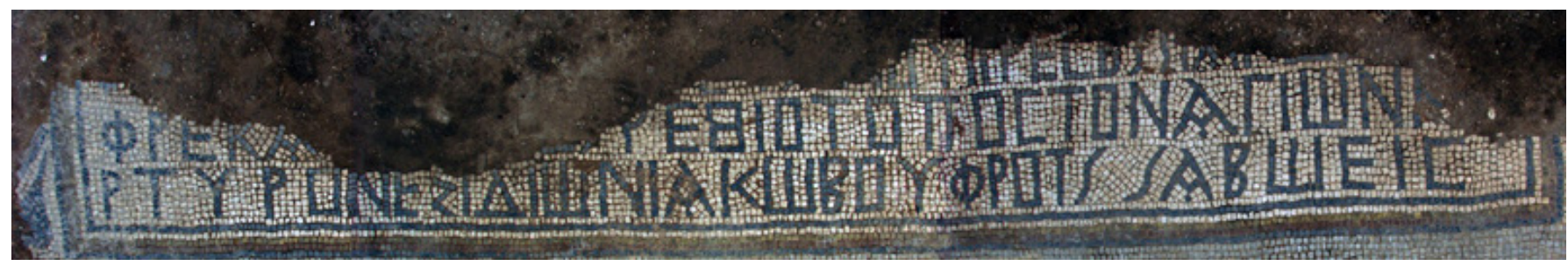

Mozaikteki yazıt, Prof. Dr. Hamdi Sayar ${ }^{1}$ tarafindan “.......rahipliği döneminde bu kutsal martyrium'un sorumlusu Yakob kendi kesesinden (yaptırdl)" şeklinde çevrilmiştir.

\section{Bölüm}

II. bölüm, 1,05 x 2,80 m ölçülerinde, geometrik motifler ve dört kare içerisine yerleştirilmiş kuş figürlerinden meydana gelmiştir (Res. 10 - 11, Çiz. 4).

Pano siyah, beyaz, koyu gri, açık gri, kızıl kırmızı, oksit sarı ve koyu kahverengi renk tesseralar kullanılarak yapılmıştır.

Resim 10

I. pano, II. bölüm.

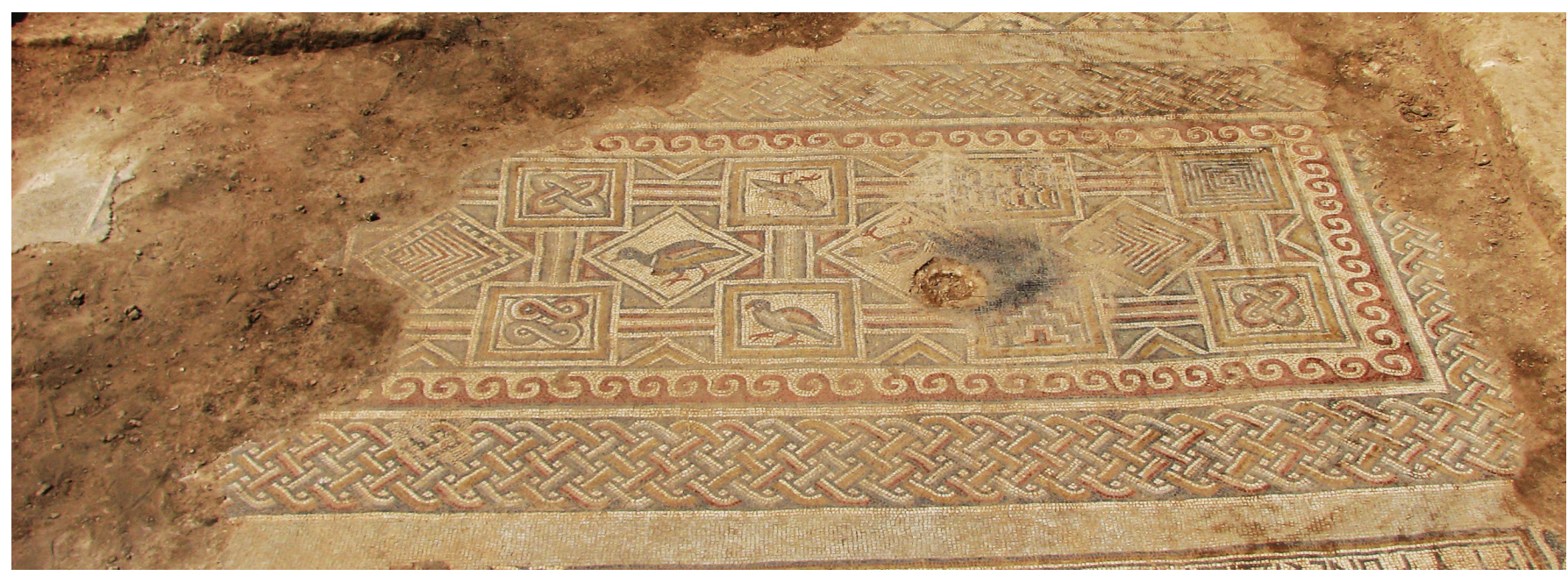

Pano yatay ve dikey yerleştirilen, birbirine bağlı kare ve karelerin bağlantılarına uçları değen eşkenar dörtgenlerden oluşan geometrik bir tasarımdan oluşmuştur. Kareler arasında oluşan boşluklar üçgen tasarımlarla doldurulmuştur. Kare ve eşkenar dörtgenlerin içerisine kuşlar ve geometrik motifler yerleştirilmiştir. II. bölümde, 4 hayvan figürü ve 8 geometrik motif, 2 bordür kullanılmıştır (Res. 10 - 11, Çiz. 4). Pano basit dalga deseni (Décor I: 101a) ve geniş gölgeli çok kollu guilloche (Décor I: pl. 73f) bordürle sınırlandırılmıştır.

1 Mozaikte tespit edilen kitabelerin çevirisi İstanbul Üniversitesi, Edebiyat Fakültesi, Eskiçağ Tarihi Bölümünden Prof. Dr. M. Hamdi SAYAR tarafından yapılmıştır. 
Resim 11

Numaralandırılmış I. pano, II. bölüm.



\section{1- Hayvan Figürleri}

F1 numaralı ördek figürü, eşkenar dörtgen içerisine yerleştirilmiştir (Res. 11 12, Çiz. 4). Eşkenar dörtgen tek sıra siyah ve çift sıra beyaz tesseralarla işlenmiş çizgiler ile sınırlandırılmıştır. Ördeğin baş bölümü yangın geçirdiği için renk değişimine uğramıştır. Figürde siyah, kızıl kahverengi, kızıl kırmızı, beyaz, kirli beyaz, koyu gri ve oksit sarı olmak üzere 7 renk kullanılmıştır. Ördek sola doğru yönelmiş, sol ayak havada, kanadı kapalı, kuyruk hafif aşağıya doğru eğimlidir. Gaga üçgen, baş oval formdadır. Göz tahribat sebebiyle belirsizdir. Boyun uzun silindir şekildedir. Gövde oval olup sırt hafif yükseltilmiştir. Kuyruk üçgenimsi bir forma sahiptir. Kanat kapalı ve çok renklidir. Kanadın ucu, kuyrukla birleşim noktasında küçük bir çıkıntı yapmıştır. Ayaklar kısa, üç parmaklı ve uçları sivridir (Res. 12).

Resim 12 F1 numaralı ördek figürü.

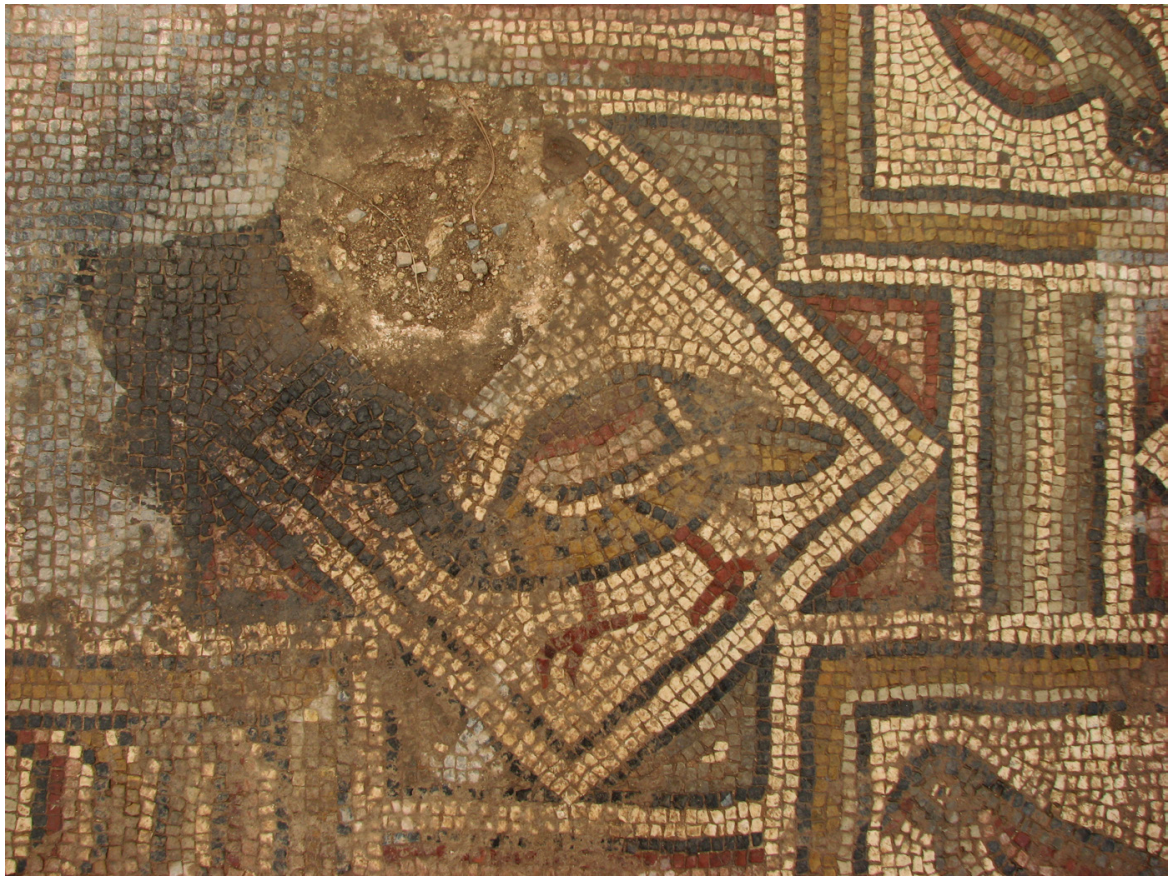


F2 numaralı kuş figürü, kare içerisine yerleştirilmiştir (Res. 11, 13, Çiz. 4). Kare siyah, beyaz, oksit sarı, açık gri renkli tek ve çift sıra tesseralarla işlenmiş çizgilerle sınırlandırılmıştır. Figürde siyah, kızıl kahverengi, kızıl kırmızı, beyaz, kirli beyaz, koyu gri olmak üzere 6 renk kullanılmıştır. Kuş sola doğru yönelmiş, bir ayak havada, kanadı kapalı, kuyruk hafif aşağıya doğru eğimlidir. Gaga üçgen, baş oval formdadır. Göz yuvarlaktır. Boyun çok kısadır. Gövde ovaldir. Kuyruk üçgenimsi bir formda olup ucu sivridir. Kapalı olan kanat çok renklidir. Kanadın ucu sivri ve kuyrukla birleşim noktasında küçük bir çıkıntı yapmıştır. Ayaklar gövdeye göre uzun, üç parmaklıdır (Res. 13).



F3 numaralı papağan figürü, kare içerisine yerleştirilmiştir (Res. 11, 14, Çiz. 4). Kare siyah, beyaz, oksit sarı, açık gri renkli tek ve çift sıra tesseralarla işlenmiş çizgilerle sınırlandırılmıştır. Figürde siyah, kızıl kahverengi, kızıl kırmızı, beyaz, kirli beyaz, koyu gri ve açık gri olmak üzere 7 renk kullanılmıştır. Papağan sola



Resim 13

F2 numaralı kuş figürü.

Resim 14

F3 numaralı papağan figürü. 
doğru yönelmiş, bir ayak havada, kanadı kapalı, kuyruk hafif aşağıya doğru eğimlidir. Baş yuvarlak, gaga üçgen formdadır. Göz ovaldir. Boyun kısa ve silindir şekildedir. Gövde ovaldir. Sırt yukarı doğru kalkıktır. Kuyruk uzun dikdörtgenimsi bir formda olup ucu sivridir. Kanat kapalı ve çok renklidir. Kanadın ucu sivri ve kuyrukla birleşim noktasında küçük bir çıkıntı yapmıştır. Ayaklar gövdeye göre uzun, üç parmaklıdır (Res. 14).

F4 numaralı ördek figürü, eşkenar dörtgen içerisine yerleştirilmiştir (Res. 11, 15, Çiz. 4). Eşkenar dörtgen tek siyah ve çift beyaz tesseralarla işlenmiş çizgilerle sınırlandırılmıştır. Figürde siyah, koyu kahverengi, kızıl kırmızı, beyaz, kirli beyaz, koyu gri ve oksit sarı olmak üzere 7 renk kullanılmıştır. Ördek sola doğru yönelmiş, sol ayak havada, kanadı kapalı, kuyruk düzdür. Baş yuvarlak, gaga üçgen formdadır. Göz yuvarlaktır. Boyun kısa silindir şekildedir. Gövde oval olup sırt hafif yükseltilmiştir. Kuyruk üçgenimsi bir forma sahiptir. Kanat kapalı ve çok renklidir. Kanadın ucu kuyrukla birleşim noktasında küçük bir çıkıntı yapmıştır. Ayaklar kısa, üç parmaklı ve uçları sivridir (Res. 15).

Resim 15 F4 numaralı ördek figürü.

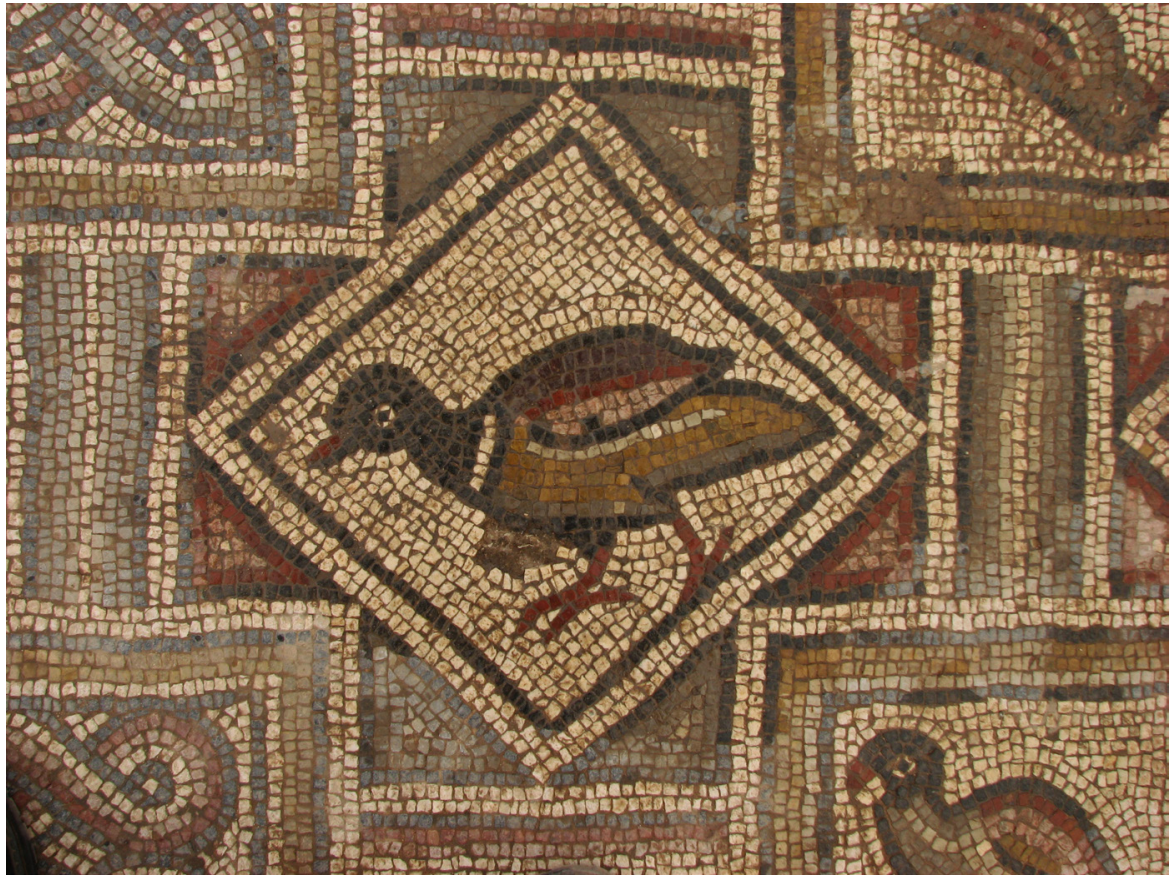

\section{2- Geometrik Motifler}

M1 numaralı geometrik motif kare düzeneğin içerisine yerleştirilmiştir (Res. 11, 16, Çiz. 4). Beyaz, siyah ve oksit sarı renkli tek ve çift sıra tesseralarla işlenmiş çizgilerle sınırlandırılmıştır. Motif siyah ve beyaz tesseralarla yapılmış, iç içe geçmiş köşeli hatlarla, sarmal biçimde, büyükten küçüğe doğru yerleştirilmiş düzenektir.

M2 numaralı Süleyman'ın Düğümü (Décor II: 42) motifi kare düzeneğin içerisine yerleştirilmiştir (Res. 11, 17, Çiz. 4). Beyaz, siyah, oksit sarı ve açık gri renkli tek ve çift sıra tesseralarla işlenmiş çizgilerle sınırlandırılmıştır. Süleyman'ın Dügümü beyaz zemine işlenmiştir. Düğümde iki farklı renk düzeneği bulunmaktadır. Birinci düzenek siyah ile sınırlandırılmış koyu gri, açık gri ve beyaz renklidir. İkinci düzenek siyah ile sınırlandırılmış, kızıl kahverengi, kirli beyaz ve beyaz renklerle işlenmiştir. 



M3 numaralı motif eşkenar dörtgen düzeneğin içerisine yerleştirilmiştir (Res. 11, 18, Çiz. 4). Siyah, beyaz, oksit sarı, açık gri renkli tek ve çift sıra tesseralarla işlenmiş çizgilerle sınırlandırılmıştır. Yatay yerleştirilmiş üst üste binmiş köşeli ayraçlardan oluşan motif (Décor I: pl.8e) siyah, beyaz ve kızıl kahverengi renk tesseralarla işlenmiştir.

M4 numaralı motif kare formlu düzeneğin içerisine yerleştirilmiştir (Res. 11, 19, Çiz. 4). Motif beyaz, siyah, oksit sarı ve açık gri renkli tek ve çift sıra tesseralarla işlenmiş çizgilerle sınırlandırılmıştır. Üst üste yerleştirilmiş, basamaklı, çift ayraçlardan oluşan ikili motifte (Décor I: pl.112e)² siyah, beyaz, koyu gri, açık gri, oksit sarı ve kızıl kahverengi renkler kullanılmıştır.

M5 numaralı motif kare formlu düzeneğin içerisine yerleştirilmiştir (Res. 11, 20, Çiz. 4). Motif siyah, beyaz, oksit sarı ve açık gri renkli tek ve çift sıra tesseralarla işlenmiş çizgilerle sınırlandırılmıştır. Şeritlerden oluşan gökkuşağı desenli kademeli dişlere sahip basit meander (Décor I: pl.200c) motifinden oluşmuştur. Motif kızıl kahverengi, kirli beyaz, beyaz, koyu gri renklerle işlenmiştir.

M6 numaralı Süleyman'ın Düğümü (Décor II: 42) motifi kare düzeneğin içerisine yerleştirilmiştir (Res. 11, 21, Çiz. 4). Beyaz, siyah, oksit sarı ve açık gri renkli tek ve çift sıra tesseralarla işlenmiş çizgilerle sınırlandırılmıştır. Dügümün uç kısımları sivri ve iki farklı renk düzeneğinde işlenmiştir. Birinci düzenek siyah ile sınırlandırılmış koyu gri, açık gri ve beyaz renklerle, ikinci düzenek siyah ile sınırlandırılmış, kızıl kahverengi, kirli beyaz ve beyaz renklerle işlenmiştir.

M7 numaralı motif kare düzeneğin içerisine yerleştirilmiştir (Res. 11, 22, Çiz. 4). Beyaz, siyah ve oksit sarı renkli tek ve çift sıra tesseralarla işlenmiş çizgilerle sınırlandırılmış ve birbirine teğet, yatay konumda çift burgu ${ }^{3}$ motifinden oluşmuştur. Motif iki farklı renk düzenekte işlenmiştir. Birinci düzenek siyah ile sinırlandırılmış koyu gri ve beyaz renklerle, ikinci düzenek siyah ile sınırlandırılmış, kızıl kahverengi, kirli beyaz ve beyaz renklerle işlenmiştir.

M8 numaralı motif eşkenar dörtgen düzeneğin içerisine yerleştirilmiş, siyah ve beyaz renkli tek ve çift sıra tesseralarla işlenmiş çizgilerle sınırlandırılmıştır (Res. 11, 23, Çiz. 4). Motifin çevresi ayrıca siyah ve beyaz renk tırtıklı çizgi ${ }^{4}$ (Décor I: pl.2) ile de sınırlandırılmıştır. Yatay yerleştirilmiş üst üste binmiş köşeli ayraçlardan (Décor I: pl.7e) oluşan motif, siyah, beyaz ve kızıl kahverengi renklerle işlenmiştir.

2 Morey bu desene "çift köşeli ayraç" ismini vermiştir (Morey 1938: 98).

3 Benzer motifler için bk. Décor I: pl.2j.

4 Balmelle bu desen tırtıklı çizgi (Décor I: pl. 2) derken Morey dişler adını vermiştir (Morey 1938: 85).
Resim 16

M1 numaralı geometrik motif.

Resim 17

M2 numaralı geometrik motif. 



Resim 18

M3 numaral1 geometrik motif.

\section{Bordürler}

Resim 19

M4 numaral1 geometrik motif.

Resim 20

M5 numaral1 geometrik motif.

Resim 21

M6 numaralı geometrik motif.

Resim 22

M7 numaral1 geometrik motif.

Resim 23

M8 numaralı geometrik motif.

Pano sırayla beyaz bir çizgi, sonra siyah, beyaz, açık gri, koyu gri, oksit sarı, kızıl kırmızı renk tesseralarla yapılmış M9 olarak adlandırılan çok kollu guilloche (Décor I: pl.73f) motifi, tekrar beyaz daha sonra koyu gri ve siyah çizgi, son olarak kızıl kırmızı ve beyaz renk tesseralarla işlenmiş M10 olarak adlandırılan basit dalga motifi (Décor I: pl.101a) bordür ile sınırlandırılmıştır (Res. 11, 24, Çiz. 4).

II. bölümden sonra gri tesseralarla yapılmış geniş bant ve banttan sonra M11 olarak adlandırılan geometrik ${ }^{5}$ düzenleme bulunmaktadır. Geometrik düzenleme siyah ve beyaz renkle işlenen iki çizgi arasına yerleştirilmiştir. Uçları birbirine ve çizgilere değen eşkenar dörtgenlerden ve bunların arasına ve ortalarına yerleştirilen geometrik motiflerden meydana gelmiştir. Eşkenar dörtgenlerin diş hatları siyah, birleşim noktaları beyaz, iç yüzeyi gri renk tesserayla işlenmiş ve merkezine kare motifler yerleştirilmiştir. Kare motif dıştan içe doğru siyah, kızıl kırmızı, kirli beyaz, beyaz ve siyah renk düzeneğine sahiptir. İki eşkenar motifin birleşmesinden ortaya çıkan üçgen boşluklara ise dış çizgiler üzerine yerleştirilmiş dikdörtgen motifler konumlandırılmıştır. Dikdörtgenler dıştan içe doğru siyah, gri, beyaz ve siyah renk düzeneğinde işlenmiştir. Motiflerin çizgilerle birleştiği noktalar, üçgen formda siyah, gri ve beyaz renk düzeneğinden meydana gelmiştir (Res. 11, 25, Çiz. 4).

\section{Bölüm}

III. bölümde beyaz zemine işlenen tabula ansata içine işlenen Grekçe kitabe bulunmaktadır (Res. 26-27, Çiz. 5-6). Kitabenin sol bölgesindeki üçgen çerçeve

5 Benzerleri için bk. Décor I: pl.15f. 



Resim 26

I. pano, III. ve IV. bölüm.

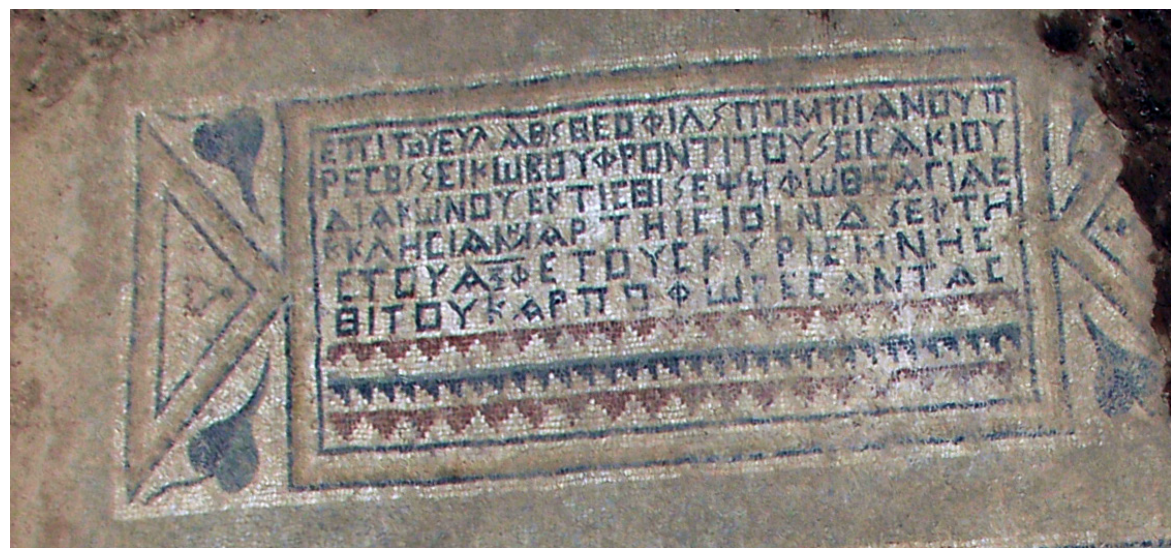

Resim 27

siyah, beyaz ve oksit sarı bordürle şekillendirilmiş ve ortasına siyah, beyaz ve kızıl kahverengi tesseralarla gül tomurcuğu işlenmiştir. Üçgen çerçeve ile dikdörtgen çerçeve arasında oluşan boşluklara kısa sapları olan iki yaprak motifi

M9 ve M10 numaral1, I. pano, II. bölüm bordürler.

Resim 25

M11 numaral1 geometrik düzenleme.
I. pano, III. ve IV. bölüm. 
Resim 28

Numaralandırılmış I. pano, III. ve IV. bölüm mozaik panolar.

Resim 29

Numaralandırılmış I. pano, III. ve IV. bölüm mozaik pano.

yerleştirilmiştir. Yapraklar siyah ve yeşil olarak iki renkli yapılmıştır. Yapraklı ve üçgen tasarım kitabenin sağ tarafında da işlenmiştir. Fakat sağ taraftaki tasarımın yarısı tahrip olmuştur. Dikdörtgen kitabenin içerisinde beyaz zemine siyah tesseralarla işlenmiş altı sıra yazı bulunmaktadır. Yazıların altında sırasıyla kızıl kırmızı ve aralara serpiştirilmiş kahverengi tesserayla işlenmiş M1 olarak adlandırılan testere dişli (Décor I: pl.10g) motif (Res. 28 - 29, Çiz. 5 - 6), altında gri çizgiye yerleştirilmiş siyah renk tesseralarla işlenmiş M2 olarak adlandırılan düz zemine işlenmiş renklendirilmiş üçgenler (Décor I: pl.12d) (Res. 28 29, Çiz. 5 - 6), onun da altında ilk sıradaki tasarımın aynısı yerleştirilmiştir. Kitabenin altında figürlü pano bulunmaktadır.
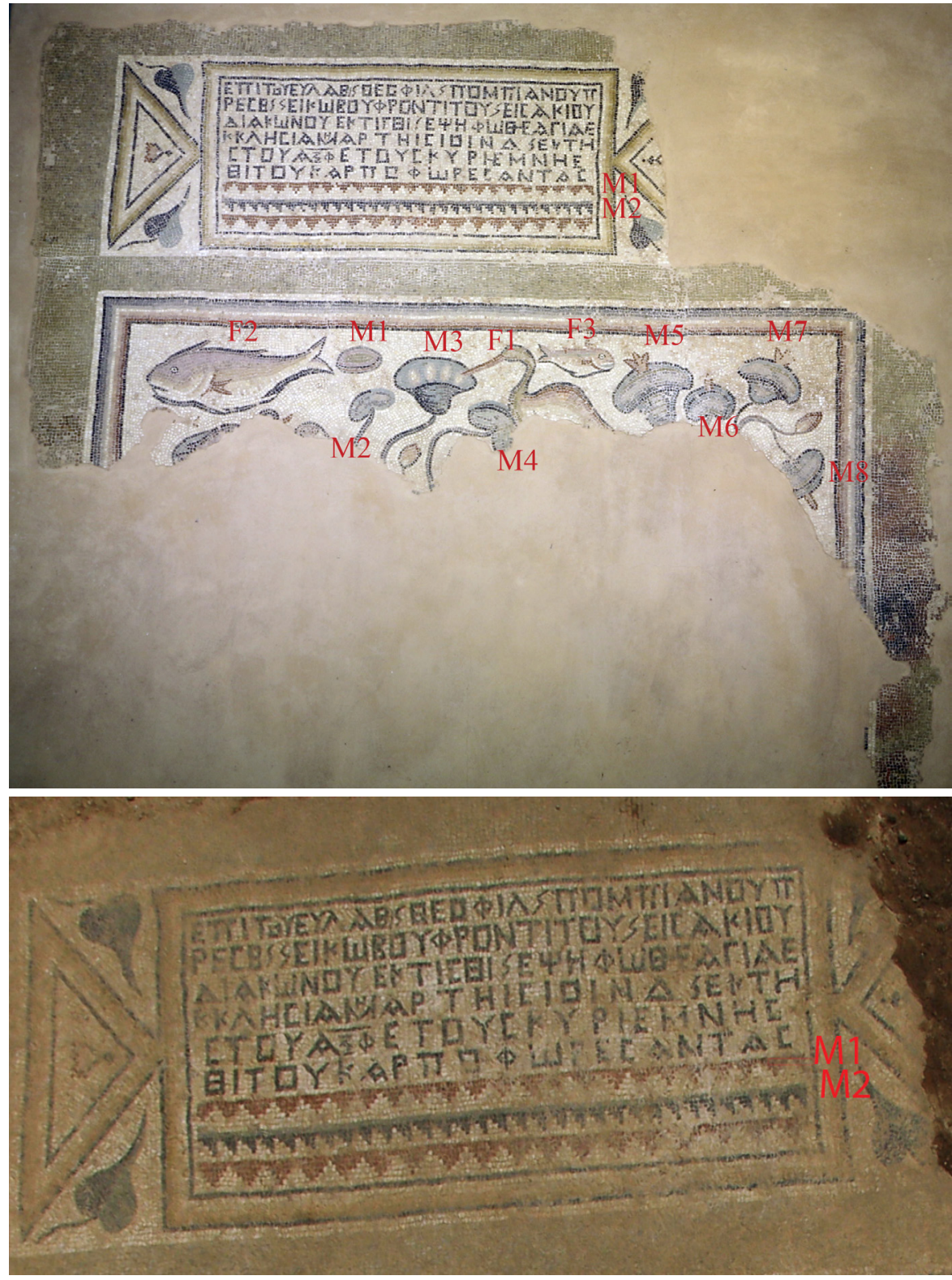

Mozaikteki yazı, Prof. Dr. Hamdi Sayar' tarafından "Çok saygın Pompeianus oğlu Theophilos'un rahipliği döneminde Yakob'un sorumlu olduğu ve İsak' in diakon olduğu dönemde bu kutsal kilisenin zemininin mozaik döşemesi 561 yıl Arteisioin (=Artemision) ayının 4. Günü tanrıya bağlılığın göstergesi olarak yaptırıldı" şeklinde çevrilmiştir.

6 Mozaikte tespit edilen kitabelerin çevirisi İstanbul Üniversitesi, Edebiyat Fakültesi, Eskiçağ Tarihi Bölümünden Prof. Dr. M. Hamdi SAYAR tarafından yapılmıştır. 


\section{Bölüm}

IV. bölüm 3 x 2,91 m ölçülerindedir. III. bölüm ile IV. bölüm geniş gri renk bantla ayrılmaktadır. IV. bölüm büyük oranda tahrip olmuştur. Pano, balıklar, leylek ve göl nilüferlerinden meydana gelmiştir (Res. 26, 28, Çiz. 5).

\section{1-Hayvan Figürleri}

F1 numaralı leylek figürü, nilüferlerin arasında, sola yönelmiştir. Leylek kızıl kahverengi, lila, siyah, beyaz, kirli beyaz ve çamurlaşmış yeşil renk tesseralarla olmak üzere 6 renkle işlenmiştir. Leyleğin başı ovaldir. Gagası uzun, kapalı ve çift renklidir. Göz tek tesserayla verilmiştir. Boyun ince uzundur. Gövde geniş fakat tahrip olmuştur (Res. 26, 28, 30, Çiz. 5).

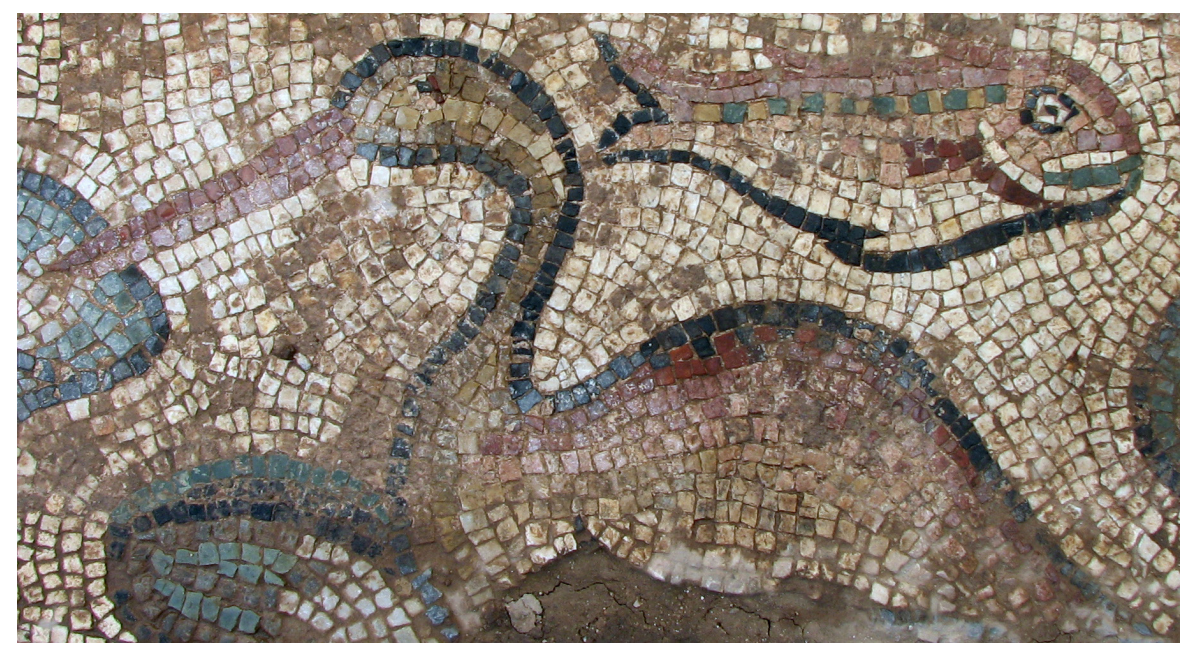

F2 numaralı balık (sazan) figürü, panonun solunda ve sola yönelmiştir. Balık siyah, kahverengi, lila, uçuk sarı, kirli beyaz ve beyaz renk tesseralarla olmak üzere 6 renkle işlenmiştir. Sazanın başı ve gövdesi geniş olup kuyruk dardır. Balığın üst ve alt kısımlarında ikişer yüzgeç, baş ile gövdenin birleştiği yerde iki çıkıntılı bir yüzgeç bulunmaktadır. Göz yuvarlak ağız düz çizgi şeklindedir. Balığın altında figür veya motif olduğu anlaşılamayan parçalar bulunmaktadır (Res. 26, 28, 31, Çiz. 5).



F3 numaralı balık (sazan) figürü, leyleğin üstünde sağa yönelmiştir. Balık siyah, beyaz, yeşil, açık kahverengi, kızıl kahverengi, kirli beyaz renk tesseralarla olmak üzere 6 renkle işlenmiştir. Balığın başı ve gövdesi bir bütün gibi olup baş oval formdadır. Göz yuvarlak, ağız geniş uzun düz çizgi şeklindedir. Kuyruk kısa ve iki çatallıdır. Balığın sırtında iki, karnında ve gövdede bir yüzgeç bulunmaktadır (Res. 26, 28, 30, Çiz. 5).
Resim 30

I. pano, IV. bölüm. F1 numaralı leylek figürü ve F3 numaralı balık figürü.

Resim 31

I. pano, IV. bölüm. F4 numaralı balık figürü. 
Resim 32

II. pano.

\section{Resim 33}

Numaralandırılmış II. pano.

Çizim 7

II. pano.

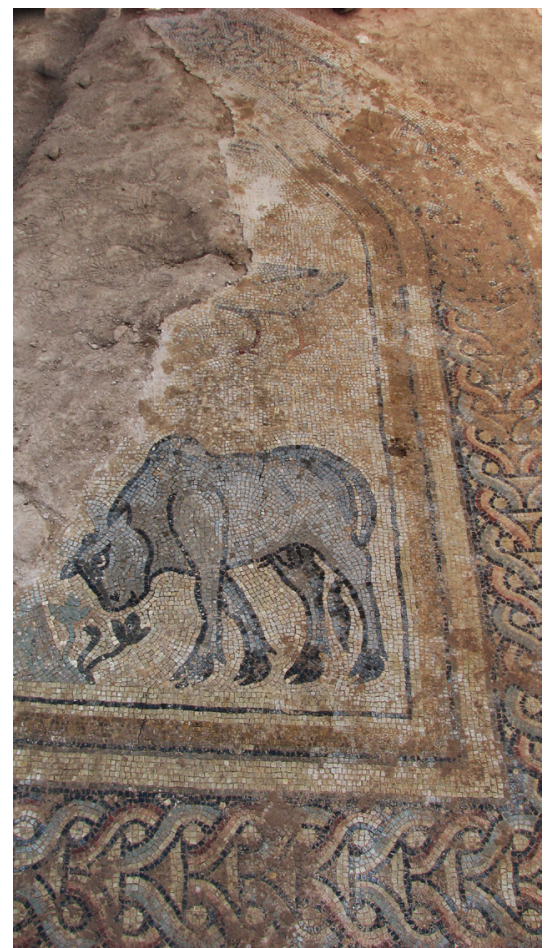

\section{2- Bitkiler}

Nilüferler siyah, beyaz, yeşil ve lila renklerle işlenmiştir. Nilüferin sapları siyah ve yeşil olarak iki renklidir. M1 numaralı nilüfer tek başına ve sapsız olarak yapılmıştır (Res. 26, 28, Çiz. 5). M2 numaralı nilüfer oval formdadır (Res. 26, 28, Çiz. 5). M3 numaralı nilüfer geniş olup iç kısmında dört adet beyaz yaprak motifleri yerleştirilmiştir (Res. 26, 28, Çiz. 5). M4 numaralı nilüfer de oval şekildedir (Res. 26, 28, Çiz. 5).

M5 numaralı nilüferlerin üst kısmında üçlü yaprak bulunmaktadır (Res. 26, 28, Çiz. 5). M6 numaralı nilüferin üstünde ise tek yaprak bulunmaktadır (Res. 26, 28, Çiz. 5). M7 numaralı nilüfer (Res. 26, 28, Çiz. 5) M5 numaralı nilüfer gibi üç yapraklıdır. M8 numaralı nilüferin yarısı tahrip olmuş fakat gövdesinden yapraklı bir dal çıkmıştır (Res. 26, 28, Çiz. 5).

\section{3- Bordür}

Figürlü pano geniş gri, ince beyaz çizgi ile çevrilmiş olup iç kısımda siyah, koyu gri, açık gri, beyaz, kirli beyaz, lila ve kızıl kahverengi renk tesseralarla asimetrik gölgeli bant (Décor I: pl.6c) bulunmaktadır (Res. 26, 28, Çiz. 5).

\section{Pano}

II. pano martyriumun farklı bir mekânında olup tahrip olmuştur. II. pano oval forma yakın 1,85 m x 3,37 m ölçülerindedir (Res. 32, Çiz. 7).

Panonun yarısı mevcut olup bir kuşun sadece kuyruğu, altında başka bir kuşun gövdesi, en altta ise boğa yer almaktadır. Boğanın önünde tahrip olan ağacın gövde parçası ve otlar bulunmaktadır (Res. 32, 33, Çiz. 7).


\section{1-Hayvanlar}

F1 numaralı figür, panonun en üstünde olup cinsi belirsiz bir kuşun sadece kuyruk bölümüdür. Kuyruk siyah, gri ve beyaz renk olmak üzere 3 farklı renk tesserayla işlenmiştir (Res. 32, 33, 34, Çiz. 7). F2 numaralı kuş figürünün kafa, 




boyun ve gövdesinin bir bölümü tahrip olmuştur (Res. 32, 33, 35, Çiz. 7). Kuş siyah, beyaz, koyu gri, kızıl kahverengi ve oksit sarı renk olmak üzere 5 farklı renk tesserayla işlenmiştir. Kuş, sola doğru yönelmiş, kanadı kapalı, kuyruğu yukarıya doğru kalkmıştır. Öndeki ayak havada ve açık renkli, gerideki ayak yere basıyor ve koyu renklidir. Üç parmaklı işlenmiştir. Parmaklar hafif kavisli, ucu sivri şekildedir. Parmakların üstünde küçük bir tırnak çıkıntısı bulunmaktadır.

F3 numaralı boğa, siyah, beyaz, koyu gri ve açık gri renk olmak üzere 4 farklı renk tesserayla işlenmiştir (Res. 32, 33, 36, Çiz. 7). Boğa sola doğru yönelmiş, başı önündeki ota eğilmiştir. Sırtında bir çıkıntı bulunmakta, kuyruğu aşağıya sarkmış ve ayaklarının arasındadır. Ayaklar hareketlidir. Boğanın boynuzları yukarıya doğru ve hafif iç bükeydir. Kulaklar yanlara açılmış ve üçgen formludur. Göz oval, burun nokta, ağız çizgi şeklindedir. Gövde dolgun ve iridir. Kuyruk hafif dalgalı, ucu geniştir. Ayaklar gergin, toynaklar çatallıdır.

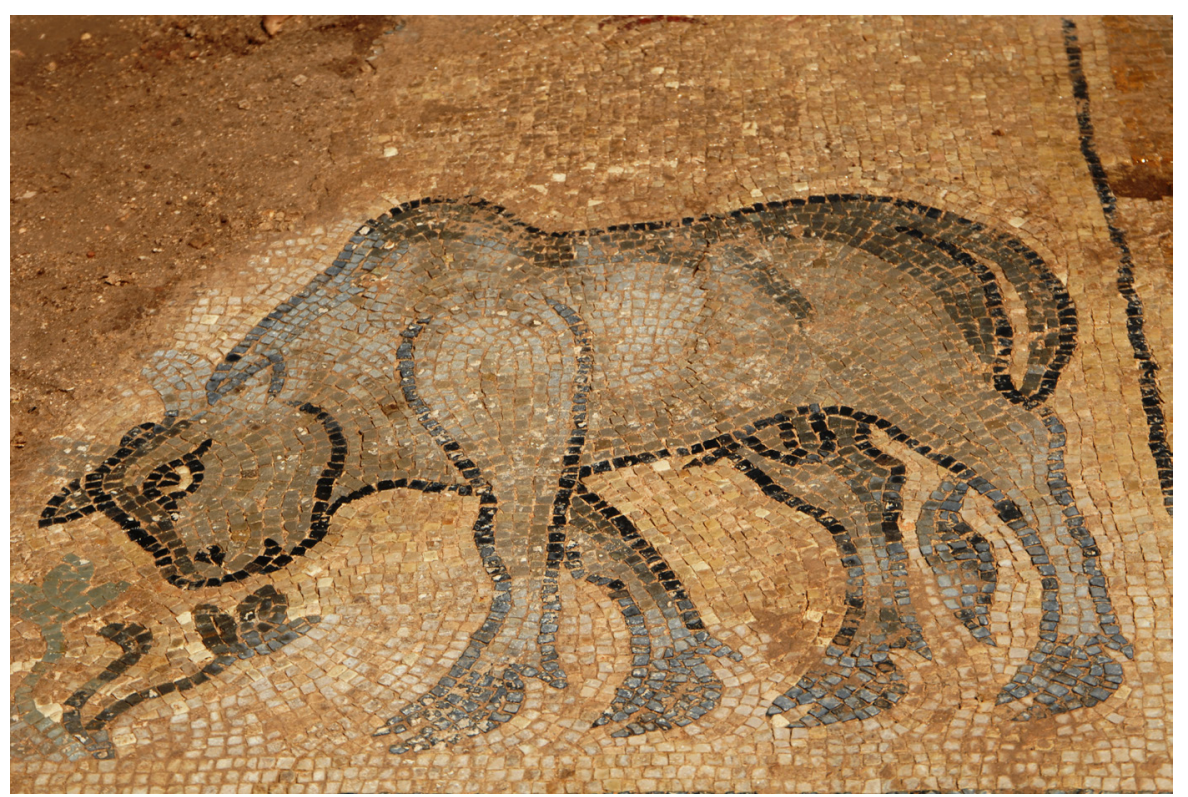

Resim 36

F3 numaralı boğa figürü. 


\section{2- Bitkiler}

M1 numaralı ağacın gövdesi hafif sola eğimli ve gri renk tesserayla işlenmiştir (Res. 32, 33, Çiz. 7). M2 numaralı ot figürleri ağacın kök kısmındadır (Res. 32, 33, Çiz. 7). Otların biri gri diğeri siyah renk tesserayla işlenmiştir. Açık olan otun gövdesi kısa, hafif dalgalı ve ucunda üçlü yaprak bulunmaktadır. Koyu renkli otun iki gövdesi bulunmaktadır. Birinci gövde, hafif dalgalı olup ucu gövdeye göre daha geniştir. İkinci gövde, sağa doğru hafif yatmış ve ucunda üçlü yaprak bulunmaktadır.

\section{3-Bordür}

Pano iki bordürle sınırlandırılmıştır. Dıștaki bordür M3 olarak adlandırılan guilloche (Décor I: pl.74h) motifidir. Bordür siyah, koyu gri, açık gri, kirli beyaz, kızıl kahverengi, açık pembe, oksit sarı renklerle işlenmiştir. İç bordür asimetrik gölgeli bant ve simetrik gölgeli bant (Décor I: pl.6b) şeklinde siyah, beyaz ve oksit sarı renklerle işlenmiştir (Res. 32, 33, Çiz. 7).

\section{Pano}

\section{1-Bordür}

III. pano bordür parçası (Res. 37, Çiz. 8), II. pano ile aynı mekân içerisindedir. III. panonun parçası olan bordür, $1,11 \mathrm{~m}$ x $0,83 \mathrm{~m}$ ölçülerindedir. Bordür geometrik olup tahrip olmuștur. Siyah, beyaz, kirli beyaz, açık gri, koyu gri, oksit sarı, kızıl kahverengi ve açık sütlü kahverengi renklerle işlenmiştir. Geometrik bordür oksit sarı bir bantla sınırlandırılmıştır. Merkeze yerleştirilen geometrik motifin dış bordürü beyaz, açık gri, siyahla işlenmiş asimetrik gölgeli bant ile sınırlandırılmıştır. Merkezdeki geometrik şekiller oksit sarı zemine işlenmiştir. Uçları birbirine ve bordüre değen eşkenar dörtgenler ile ortasına yerleştirilen daha küçük eşkenar dörtgenler ve bordüre değen üçgen geometrik şekillerden meydana gelmiştir. Büyük eşkenar dörtgenler siyah tesseralarla çizgisel yapılmıştır. Küçük eşkenar dörtgenler ise siyah, kızıl kahverengi, kirli beyaz,

III. pano geometrik bordür parçs
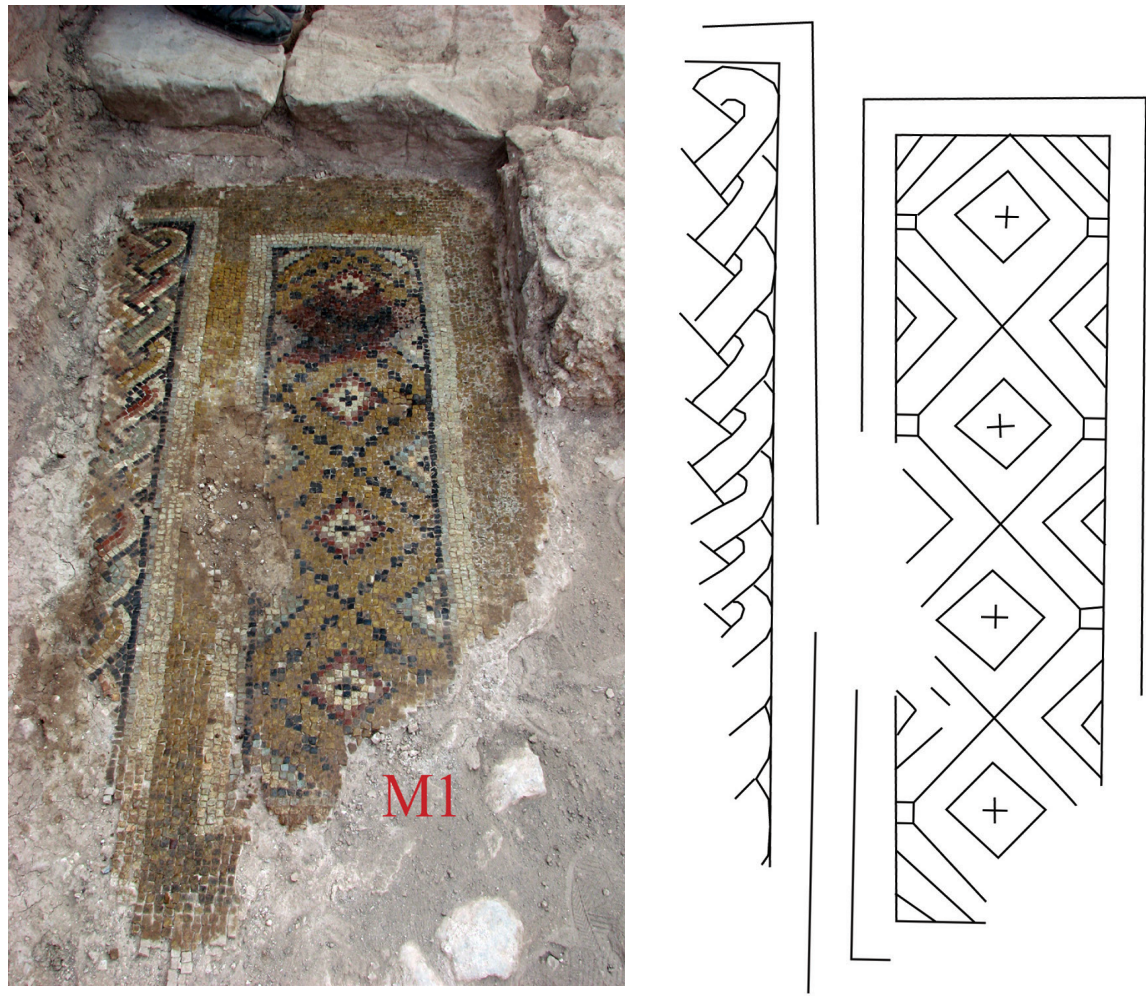

Çizim 8

III. bölüm. 
beyaz renklerle işlenmiş olup merkeze "+ (artı)" şeklinde motif yerleştirilmiştir. Bordüre yerleştirilen üçgenler ise siyah, açık gri, koyu gri ve beyaz renklerle işlenmiştir. Dikdörtgen formdaki geometrik panodan sonra beyaz, gri ve siyah renklerle işlenmiş asimetrik renkli banttan sonra tahrip olmuş guilloche motifi bulunmaktadır.

\section{Hatay Mozaikleri Arasındaki Yeri}

\section{Kompozisyon - Konu - Figür - Motif - Ölçü - Renk - Cins}

Hatay İli sınırları içerisinde 1932 yılında arkeolojik kazılar başlamış (Morey 1938: 27; Barsanti 2012: 25-42) ve günümüze kadar olan süreçte çok sayida arkeolojik kazı yapılmıştır. Kazılarda ortaya çıkan mozaikler genelde sivil ve dini mimari içerisinde yer almaktadır. Sivil yapılarda olduğu gibi dini yapılarda ortaya çıkarılan mozaiklerde kompozisyon, konu, motif ve figür çeşitliliği bulunmaktadir.

Hatay genelinde kilise, bazilika veya martyrium kazılarında ortaya çıkarılan mozaiklerde cennet tasvirli konular sık işlendiği gibi dini olaylar, portreler, hayvan, bitki ve geometrik motifler de işlenmiştir. Yapının işlevi yani dini yapı ile mozaik panoların konusu bütünlük içerisinde olup İncirli Köyü Martyrium Mozaiği de bu bütünlüğün bir parçası olarak Hatay'da bulunan mozaiklerin içerisinde yerini almaktadır. İncirli Köyü Martyrium Mozaiği’nin, Hatay Mozaikleri içerisindeki yerini anlamak için İncirli Köyü Martyrium Mozaiği’ni özellikle İS II. - İS V. yüzyıl arasına tarihlendirilen bazı mozaiklerle konu, kompozisyon, figür ve motifleri ile karşılaştırmak gerekmektedir.

Hatay'da çıkarılan mozaiklerin kompozisyonlarının İncirli Köyü Martyrium Mozaiği ile benzer yanları olduğu gibi farklılıkları da bulunmaktadır.

1937 y1lında Hatay - Harbiye'de bulunan İS IV. yüzy1la tarihlenen "Masklar" (Levi 1945: 307 fig. 126) mozaiğinin genel kompozisyon tasarımı İncirli Mozaiği I. pano II. bölüm (Res. 10, Çiz. 9) ile benzer olup bazı farklılıklar da vardır. Masklar Mozaiği’nde kompozisyonun şablonunda üç sıralı geometrik bir düzenleme, Martyrium II. bölüm mozaiğinde ise iki sıralı (Çiz. 9) bir düzenleme mevcuttur. Tasarım olarak birbirine bağlı kareler ve dört karenin oluşturduğu boşluğa yerleştirilen eşkenar dörtgen düzenlemesi ve karelerin bordür bağlantısının olduğu bölgelere yerleştirilen üçgenler her iki mozaik panoda aynidır (Res. 10).

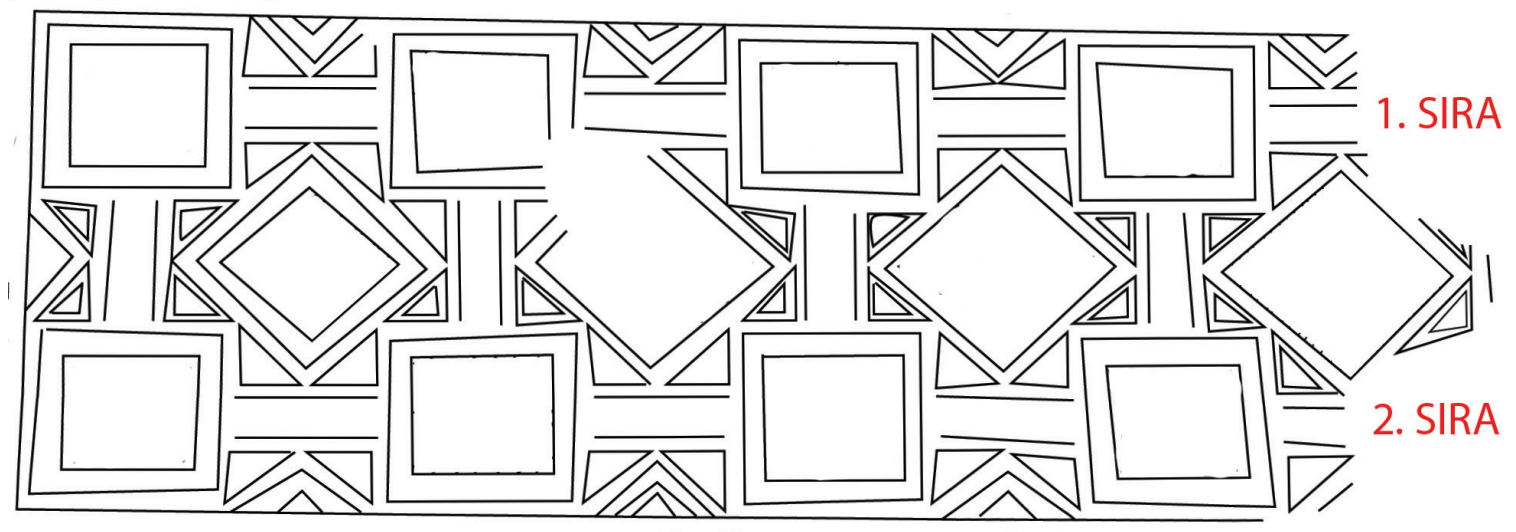

İncirli Mozaiği I. pano II. bölümde kullanılan kareler içerisine yerleştirilen M4 (Res. 19) ve M5 (Res. 20) geometrik motifler, Masklar Mozaiği'ndeki geometrik motiflerle benzer olup diğer geometrik motifler farklıdır. İki mozaik panoda 
bulunan eşkenar dörtgenler içerisinde; Martyrium II. bölümde kompozisyon tasarımında kuş (Res. 10), Masklar Mozaiği'nde ise masklar işlenmiştir. Martyrium II. bölüm mozaiği iki bordürle sinırlandırılırken (Res. 10), Masklar Mozaiği ise tek geometrik bordürle sınırlandırılmıştır. II. bölüm ile Masklar Mozaiği'ndeki kompozisyon tasarımındaki önemli bir fark ise Martyrium II. bölüme yerleştirilen kitabedir.

İncirli Köyü Martyrium Mozaiği, I. pano II. bölüm (Res. 10, Çiz. 4, 9) tasarımına benzer tasarım Antakya'da Kuş Sarmalı (Levi 1945: 257, 258) Evi'nde bulunmaktadır. Kuş Sarmalı Mozaiği'nde kompozisyon tasarımı, Martyrium II. bölümden farklı olmasına rağmen genel özellikler benzerdir. Kuş Sarmalı Evi'ndeki panonun merkezine geniş geometrik motif yerleştirilmiş olup Martyrium II. bölümdeki gibi tasarım geometrik panonun çevresini sarmıştır. Kuş Sarmalı Evi'ndeki mozaik panoda kare ve eşkenar dörtgenlerin içi tamamen geometrik motiflerle doldurulmuş olup hiç figür kullanılmamış olup martyrium II. bölüm mozaiğinde geometrik motifin yanında figürler de kullanılmıştır. Martyrium II. bölüm mozaiğinde M3 (Res. 18) ve M4 (Res. 19) numaralı motifler Kuş Sarmalı Mozaiği'ndeki düzenlemelerle benzerdir. Kuş Sarmalı Evi'ndeki mozaik tek geometrik bordürle sınırlandırılmıştır. II. bölüm ile Kuş Sarmalı Evi Mozaiği arasındaki önemli bir kompozisyon tasarım farkı ise II. bölümüne yerleştirilen kitabedir.

İncirli Mozaiği'nde, Martyrium I. pano II. bölüm tasarımına benzer tasarım Ananeosis Mozaiği'nde de görülmektedir (Campbell 1940: 419 fig. 5). Bu mozaik, Antakya'da bulunmuş ve İS V. yüzylla tarihlendirilmiştir. Ananeosis Mozaiği’nin kompozisyon tasarımı, İncirli Köyü Martyrium Mozaiğinin I. pano II. bölümünden (Res. 10, Çiz. 4, 9) farklı olmasına rağmen genel özellikleri benzerdir. Ananeosis Mozaiği kompozisyonunda altı sıralı bir düzenleme, İncirli Mozaiği II. bölümde ise iki sıralı bir düzenleme mevcuttur. Martyrium I. pano II. bölümdeki tasarımın benzeri Ananeosis'in çevresini sarmıştır. İki mozaikte tasarım olarak birbirine bağlı kareler ve ortalarına yerleştirilen eşkenar dörtgen düzenlemesi aynıdır. Kare ve eşkenar dörtgenlerin içi tamamen geometrik motiflerle doldurulmuş olup hiç figür kullanılmamıştır. Eşkenar dörtgenlerde ise Martyrium II. bölümde kuş, Ananeosis Mozaiği'nde ise geometrik motifler işlenmiştir. Karelerin bordür bağlantısının olduğu bölgelere yerleştirilen üçgenler de aynıdır. II. bölüm mozaiğinde kareler içerisine yerleştirilen M2 (Res. 17) ve M4 (Res. 19) gibi iki geometrik motif, Ananeosis Mozaiği'ndeki motiflerle benzer olup diğer motifler farklıdır. II. bölüm iki bordürle sınırlandırılırken, Ananeosis Mozaiği ise bir bitkisel üç geometrik bordürle sınırlandırılmıştır. İncirli Mozaiği II. bölüm ile Ananeosis Mozaiği arasındaki önemli bir kompozisyon farkı ise II. bölümün güneydoğu bölümüne yerleştirilen kitabenin Ananeosis Mozaiği’nde bulunmamasidır.

Antakya'da bulunan İS IV. yüzyıla tarihlenen E Hamamı'nın (Campell 1938: 10 pl. 37) bir odasında bulunan mozaik panonun kompozisyon tasarımının İncirli Köyü Martyrium Mozaiği I. pano II. bölümden (Res. 10, Çiz. 4, 9) farklı olmasına rağmen genel özellikleri benzerdir. Hamam E'de, oda tabanında bulunan mozaikte kompozisyon dört sıralı, Martyrium II. bölümde ise iki sıralı bir düzenlemeye sahiptir. Eşkenar dörtgenlerin ortasına Martyrium II. bölümde kuş, Hamam E'de ise geometrik motif yerleştirilmiştir. Hamam E'de hiç figür kullanılmamıştır. İki mozaik panoda tasarım olarak birbirine bağlı kareler ve ortalarına yerleştirilen eşkenar dörtgen düzenlemesi aynıdır. Karelerin bordür bağlantısının olduğu bölgelere yerleştirilen üçgenler aynıdır. İncirli Mozaiği’ndeki kareler içerisine yerleştirilen kısmen M2 (Res. 17) ve M5 (Res. 
20) olmak üzere iki geometrik motif Hamam E Mozaiği’ndeki motiflerle benzer, diğer motifler ise farklıdır. II. bölüm iki bordürle sınırlandırılırken, Hamam E Mozaiği'nde ise bir geometrik bordürle sınırlandırılmıştır. İncirli Köyü Mozaiği Martyrium II. bölüm ile Hamam E Mozaiği arasındaki önemli bir tasarım fark1 ise II. bölümün güneydoğu bölümüne yerleştirilen kitabenin Hamam E Mozaiği'nde bulunmamasıdır.

Antakya'da bulunan İS IV. yüzyıla tarihlenen Hamam D (Campell 1938: 15 pl. 49) oda 3 ve 28 'de bulunan mozaik panoların, kompozisyon tasarımlarının genel özellikleri, İncirli Köyü Martyrium Mozaiği I. pano II. bölüm (Res. 10, Çiz. 4 , 9) ile benzerdir. Hamam D, oda 28 'de bulunan mozaikte kompozisyon dört sıralı bir düzenleme şeklinde yapılmıştır. Oda 3'deki panolar tahribat nedeniyle belirsiz olup Martyrium II. bölümde iki sıralı bir düzenleme şeklinde yapılmıştır. Hamam D ozaiklerinde, kare ve eşkenar dörtgenlerin içi tamamen geometrik motiflerle doldurulmuş olup hiç figür kullanılmamıştır ancak Martyrium I. pano II. bölümde kullanılmıştır.

II. bölümdeki karelerin bordür bağlantısının olduğu bölgelere yerleştirilen üçgenler, Hamam D'de bulunan panolarda görülmemektedir. Tasarım olarak birbirine bağl1 kareler ve ortalarına yerleştirilen eşkenar dörtgen düzenlemesi her iki mozaikte de aynıdır. II. bölüm ile Hamam D Mozaiği arasındaki önemli bir tasarım farkı ise II. bölümün güneydoğu bölümüne yerleştirilen kitabenin Hamam D Mozaiği’nde bulunmamasıdır.

Antakya'da saha 25/L'de (Levi 1945: CXXb) bulunan mozaik panonun kompozisyon tasarımının İncirli Köyü Martyrium Mozaiği I. pano II. bölümden (Res. 10, Çiz. 4, 9) farklı olmasına rağmen genel özellikleri benzerdir. Saha 25/L'de bulunan mozaikte kompozisyon, Martyrium II. bölümdeki gibi iki sıralı bir düzenleme şeklindedir. Her iki mozaik panoda tasarım olarak birbirine bağlı kareler ve ortalarına yerleştirilen eşkenar dörtgen düzenlemesi aynıdır. Saha 25/L Mozaiği'nde kare ve eşkenar dörtgenlerin içi tamamen geometrik motiflerle doldurulmuş olup hiç figür kullanılmamıştır fakat Martyrium I. pano II. bölümde figür kullanılmıştır. II. bölümdeki karelerin bordür bağlantısının olduğu bölgelere yerleştirilen üçgenler, saha 25/L'de bulunan panolarda görülmemektedir. Saha 25/L'de bulunan mozaikte dış bordür geometriktir. Martyrium II. bölüm ile Saha 25/L Mozaiği arasındaki önemli bir tasarım farkı ise II. bölümün güneydoğu bölümüne yerleştirilen kitabenin Saha 25/L Mozaiği'nde bulunmamasıdır.

Martyrium I. pano II. bölümde M2 (Res. 17) olarak adlandırılan Süleyman'ın Dügümü geometrik motifi ile İS V. yüzyıla tarihlendirilen (Campbell 1940: 419 fig. 5) Ananeosis Mozaiği'ndeki motif aynıdır. İS II. yüzyıla tarihlendirilen (Jones 1981: 6) İçki Yarışması Evi'ndeki oda 1'de (Levi 1945: pl. CI, b), Psykheler Kayığı Evi'nin (Levi 1945: pl. XXXVIII,d) ön oda mozaiğinde, İS II. yüzyıla tarihlendirilen Trajan Akvadüğü Mozaiği'nde (Levi 1945: pl. XCIV,a) ve Büfe Mozaiği’nin (Levi 1945: pl. XLVIII,d) batı kompleksinde bulunan odadaki mozaikte M2 motifine benzer motifin kullanıldığı görülmektedir.

Anka Kuşu Evi (Levi 1945: pl. LXXXIII,b) Mozaiği’nin bordür bölümünde M2 motifine benzer motifin bulunmasının yanında farklı versiyonda işlenen motif de bulunmaktadır. M2 olarak adlandırılan geometrik motif çok az farklı düzenleme ile Kuş Sarmalın Evi Mozaiği'nde (Levi 1945: pl. XCII,b), İS IV. yüzyıla tarihlendirilen Hamam E Mozaiği'nde (Campbell 1938a: 10 fig. 38), Hamam A Mozaiği'nde (Levi 1945: pl. CX,d) ve İS IV. yüzylla tarihlendirilen Hamam C Mozaiği'nde (Levi 1945: pl. CXVIII,d) işlenmiştir.

Martyrium I. pano II. bölümde M3 (Res. 18) olarak adlandırılan geometrik 
motifin benzeri Ananeoisis Mozaiği' nde (Levi 1945: plate CXXXI,c) işlenmiştir.

İncirli Köyü Martyrium Mozaiği I. pano II. bölümde M4 (Res. 19) olarak adlandırılan geometrik motif ile Masklar Mozaiği'ndeki (Levi 1945: 307) motif benzer olup Masklar Mozaiği'ndeki daha büyük işlenmiştir. M4 olarak adlandırılan motifin benzerleri Constatin Villası (Levi 1945: pl. LIII,a), Ge Evi (Levi 1945: 307 pl. LXXXII), Büfe Mozaiği (Levi 1945: pl. CXXV,a), Ananeoisis Mozaiği (Campbell 1940: 419, 421 fig. 5; Levi 1945: pl. CXXI,b) ve Kuş Sarmalı (Levi 1945: pl. XCII-b) mozaiklerinde görülmektedir. İncirli Köyü Martyrium Mozaiği I. pano II. bölümde M5 (Res. 20) olarak adlandırılan geometrik motif ile Masklar Mozaiği'ndeki (Levi 1945: 307) motif benzer olup Masklar Mozaiği'ndeki daha büyük işlenmiştir.

M5 (Res. 20) olarak adlandırılan geometrik motif ile Ge Evi Mozaiği'ndeki (Levi 1945: pl. LXXXII,a) ve Hamam E'de oda 10'da (Campbell 1938a: 10; Levi 1945: pl. CIX) bulunan mozaikteki motif benzerdir. İncirli Köyü Martyrium Mozaiği I. pano II. bölümde M8 (Res. 23) olarak adlandırılan geometrik motif aynı pano içerisinde çok az tasarım farkıyla M3 (Res. 18) motifine benzemektedir.

İncirli Köyü Martyrium Mozaiği I. pano II. bölümde F1 (Res. 10, 11, 12, Çiz. 4) ve F4 (Res. 10, 11, 15, Çiz. 4) olarak verilen ördek figürüne birebir benzer figürler Antakya Mozaikleri içerisinde bulunmamakla birlikte Mevsimler Evi'nde oda 4'de (Levi 1945: pl. LXXXII,b) bulunan mozaikte, Rasim Adalı (Levi 1945: pl. LXXXIV,b) arazisindeki mozaikte, Samandağ Martyrium (Levi 1945: pl. LXXXVIII,a,b) Mozaiği'nde ve İS VI. yüzyıla tarihlendirilen Kitisis Evi'nde oda 2'de (Levi 1945: pl. CXXXVII,c) ördek figürleri işlenmiştir.

İncirli Köyü Martyrium Mozaiği I. pano II. bölümde gölgeli çok kollu guilloche motifinin (M9) (Res. 11, 24, Çiz. 4) benzer versiyonunu pano şeklinde Hamam C'de (Levi 1945: pl. CXIX, a) görmekteyiz. Fakat gölgeli çok kollu guilloche motifinin daha dar örneği Comus Mozaiği'nde (Levi 1945: pl. XCIV), DH 24-S Mozaiği’nde (Levi 1945: pl. XCVII) ve Büfe Mozaiği’nin (Levi 1945: pl. CVII,a) bulunduğu güney kompleksindeki panoda görülmektedir.

İncirli Köyü Martyrium Mozaiği'nde panoların çevresini sınırlayan M10 olarak adlandırılan basit dalga bordür (Res. 11, 24, Çiz. 4) Hatay Mozaiklerini sınırlayan basit dalga bordürlerle birebir uyuşmaktadır.

İncirli Köyü Martyrium Mozaiği I. pano II. bölümü sınırlayan bordürün benzerlerinin en erken örneklerini Polyphemus Evi (Levi 1945: pl. II,b,c) Mozaiği'nde görmekteyiz. İS II. yüzyıla tarihlendirilen Polyphemus Evi'ndeki Polyphemus ve Galatea (Levi 1945: pl. III,a) ve Nehir Tanrıs1 (Levi 1945: pl. III,b) Mozaikleri'nde, İS II. yüzyıla tarihlendirilen Takvimler Evi (Levi 1945: pl.V,b) Mozaiği'nde, Trajan Aquadüktü Mozaiği'nde (Levi 1945: pl.V,a), Okeanos Tethys Mozaiği'nde (Campbell 1938b: 211 fig. 5), Kresis Mozaiği'nde (Campbell 1938b: 213 fig. 8), Bakha Dans1 (Morey 1935: 9 fig. 1) Mozaiği’nde benzer bordür işlenmiştir.

I. pano, II. bölümdeki M11 olarak adlandırılan geometrik düzenlemenin (Res. 25, Çiz. 4) benzer örnekleri olmasına rağmen birebir örtüşen geometrik düzenleme bulunmamaktadır. Fakat farkl11ıkları ile birlikte benzerleri İncirli Köyü I Kilise Mozaiği'nde (Çelik 2013: 4), Psykheler Kayığı Evi oda 3'de (Levi 1945: pl. XXXVII,a), İphigenya Evi oda 5'de (Levi 1945: pl. XCIV) bulunmaktadır.

Martyrium I. pano III. bölüm mozaiği olan kitabede kullanılan ve M1 olarak adlandırılan tırtıklı testere dişli (Res. 27 - 29) geometrik motifin en yakın örneğini, Antakya'da Polyphemus Evi'ndeki Polyphemus ve Galatea (Levi 
1945: pl. III,c) Mozaiği’nde, Takvimler Evindeki Sarhoş Dionysos (Levi 1945: pl. VII,b) Mozaiği'nde, Bacchic Thiasos Evi'nde (Levi 1945: pl. VII,c), Anka Kuşu Evi (Levi 1945: pl. IX,a) Mozaiği'nde, Kilikya Evi (Levi 1945: pl. IX,b) Mozaiği'nde, Narkisos Evi (Levi 1945: pl. X,b) Mozaiği'nde, Kırmızı Döşemeli Evi Oda 5'de (Levi 1945: pl. XIV,a) bulunan mozaikte, Atrium Evi, Paris'in Hükmü (Levi 1945: pl. I, a) Mozaiği’nde görmekteyiz.

Martyrium I. pano III. bölüm mozaiği olan kitabede kullanılan M2 olarak adlandırılan geometrik motifin (Res. 29, Çiz. 6) en yakın örneği Hamam F'de (Campbell 1938a: 97) kullanılmıştır.

Martyrium I. pano IV. bölüm mozaiklerinin bazı özellikleri Hatay mozaikleri içerisinde Balıklar ve Ördekler Mozaiği'ndeki (Levi 1945: pl. 79) motiflerle birtakım benzerlikler göstermektedir. Balıklar ve Ördekler Mozaiği’ndeki nilüfer çiçeği motifleri ile IV. bölümdeki M3 (Res. 26, 28) ve M4 (Res. 26, 28) olarak adlandırılan nilüfer çiçeği motiflerinin bazı özellikleri benzerdir. Martyrium I. pano IV. bölüm mozaiğindeki M2 (Res. 26, 28) ve M3 (Res. 26, 28) nilüfer çiçeği motifine benzer motif Kitisis Evinde oda 2'de (Levi 1945: pl. LXXXV,b) bulunmaktadır. Martyrium I. pano IV. bölüm mozaiğinde yer alan F2 (Res. 30) olarak adlandırılan balık figürünün benzeri Yürüyen Aslan (Levi 1945: pl. LXXIV,a; Lavin 1963: fig. 13) Mozaiği'nde görülmektedir.

II. panoda yer alan F3 (Res. 32, 33, 36) olarak adlandırılan boğa figürüne benzer figür, Hatay mozaikleri içerisinde şu an itibarı ile bulunmamaktadır.

Phila Salonu'nda (Levi 1945: pl. LXXII, a) ve Megalopsychia (Levi 1945: pl. LXXVIII,a; Downey 1963: fig. 45; Dunbabin 1999: 182; Kondoleon 2000: 8 fig. 6) Mozaiği’nde boğa figürü ise çok farklı şekilde işlenmiştir.

İncirli Köyü Martyrium Mozaiği, II. panoda yer alan M3 (Res. 33) olarak adlandırılan guilloche bordürü, Topografik (Levi 1945: pl. LXXIV,b) bordür parçasında, Ananoisis Mozaiği'nde (Levi 1945: pl. CXXXI,d) ve Yakto Mozaiği'nde (Campbell 1934: pl. XXII-A; Morey 1935: 11) benzer şekilde kullanılmıştır.

İncirli Köyü Martyrium Mozaiği, III. panoda kullanılan geometrik motif (Res. 37) biraz farklı olsa da benzeri Psykheler Kayığı Evi oda 3'de (Levi 1945 pl. XXXVII,a), Psykheler Kayığı Evi Hermaafroditi (Levi 1945: pl. XXXIX, a) koridorunda, Menander Evi oda 1'de (Levi 1945: pl. XLIV,b), Mevsim Mozaiği'nde ( Levi 1945: pl. L, d), Aion Evi'nde (Levi 1945: pl. LXXXIV,c) ve Hamam F (Levi 1945: pl. CVIII,f) binasında bulunan mozaikte işlenmiştir.

İncirli Köyü Martyriumun'da bulunan mozaik panolar farklı mekânlardadır. Mozaik panoların tahrip olması ve tabanında bulundukları mekânların tam olarak sınırlarının ortaya çıkarılamaması sebebiyle mozaiklerin ölçüleri sağlıklı değildir. İncelenen Hatay Mozaiklerinin tek panodan oluşması ve Martyrium Mozaiklerinin üç farklı panodan oluşması birbirleriyle ölçü olarak kıyaslama problemini doğurmuştur. Bu sebeple, İncirli Köyü Martyrium Mozaiği ile yukarıda karşılaştııılması yapılan Hatay Mozaiklerinin ölçüleri arasında bir kıyaslamaya gidilmemiştir.

İncirli Köyü Martyrium Mozaiği'nde siyah, beyaz, kirli beyaz, çamurlaşmış yeşil, uçuk kahverengi, koyu kahverengi, kızıl kahverengi, kızıl kırmızı, açık gri, koyu gri, lila ve oksit sarı olmak üzere 12 renk kullanılmıştır. Tessera cinsi olarak kalker kullanılmıştır. Hatay Mozaikleri içerisinde tessera renklerine ve cinslerine bazı örnekler verecek olursak Hamam D, oda 3-b'deki renkler beyaz, siyah, kırmızı, mavi, yeşil, açık yeşil, pembe, gri, mor, menekşe (Campbell 
1938a: 10) şeklinde olup tessera cinsi kalkerdir (Campbell 1938a: 17), Ananeoisis Mozaiği'nde tessera renkleri ise beyaz, siyah, koyu kırmızı, hardal sarısının iki tonu, yeşil grinin iki tonu, pembe, yeşil, kahverengi, mavi, gri, gümü, mor menekşe, turkuaz olup cinsi kalker, camdır (Campbell 1938a: 28).

$\mathrm{Bu}$ durum bize kullanılan tessera cinsi ile tessera renkleri konusunda İncirli Köyü Martyrium Mozaiği ile Hatay Mozaikleri arasında uyum olduğunu göstermektedir.

\section{Sonuç}

Sonuç olarak; İncirli Köyü Martyrium Mozaiklerinde kullanılan süsleme öğeleri Hatay Mozaiklerinin genelinde bulunmaktadır. Sivil yapılardaki mozaik süsleme ögelerinin benzerini veya farklılaşmış düzenlemesini İncirli Köyü Martyrium Mozaiklerinde görmekteyiz.

Genel olarak Hatay Bölgesinin Roma ve Geç Roma Dönemi Mozaiklerine baktığımızda İncirli Köyü Martyrium Mozaiklerinin Hatay Mozaikleri içerisinde süsleme öğelerine benzer en erken ve en geç dönem örnekleri ele alındığında; İncirli Köyü Martyrium Mozaiklerinin genel kompozisyon düzenlemesinin, Hatay Mozaikleri kapsamındaki sivil ve dini yapılarda ortaya çıkarılan mozaik panolar içerisinde bulunmadığını görmekteyiz. Bununla birlikte, İncirli Köyü Martyrium Mozaiğinin I. pano II. bölümün kompozisyonundaki şablon, bazı Hatay Mozaikleri ile benzerlik göstermektedir. Martyrium I. pano II. bölümde işlenen panonun geometrik düzenlemesi şablon (Çiz. 4, 9) olarak bugünkü bilgiler 1şı̆̆ında en erken Masklar Mozaiği ile Hatay'da İS IV. yüzyılda görülmeye başlamıştır.

Konu olarak ele alındığında, İncirli Köyü Martyrium Mozaiği'ndeki I. pano IV. bölümdeki göl tasviri, Hatay Mozaikleri içerisinde, bir yerde, balıklar ve ördekler mozaiğinde kullanılmış fakat kilise zemini olarak işlenmiştir. Konu olarak iki mozaik pano birbirinden farklıdır. İncirli Mozaiği'ndeki II. panoda yer alan ağaç gövdesi yanındaki boğa ve üstteki kuşlarla işlenen bir konu, diğer Hatay mozaikleri içerisinde yoktur fakat Philla Salonu'nda bulunan mozaikte, ağacın önünde boğa ve karşısında bir aslan ile işlenen pano bulunmakla birlikte bu pano dini mekânda değildir. Ayrıca her iki mozaiğin konu ve tasarımı birbirinden tamamen farklıdır.

Figürler ele alındığında, İncirli Köyü Martyrium Mozaiği, I. bölüm IV. panodaki "F2" (Res. 31) olarak gösterilen balık figürüne benzer olan en erkene tarihlendirilen örneği, İS V. yüzyıla tarihlendirilen Yürüyen Aslan Mozaiği’nde görmekteyiz.

İncirli Köyü Martyrium Mozaiğinde kullanılan, Süleyman Düğümü motifinin (Res. 17), benzer, en erkene tarihlendirilen örneğini İS II. yüzylla tarihlendirilen İçki Yarışması Evi'ndeki oda 2’ de olduğunu söyleyebiliriz.

Bordür örnekleri ele alındığında, İncirli Köyü Martyrium Mozaiği, I. pano III. bölümdeki "M1" (Res. 29) olarak adlandırılan bordür benzeri en erkene tarihlendirilen örneğini İS II. yüzyıla tarihlenen Atrium Evi'nde görmekteyiz.

Hatay mozaiklerine baktığımızda, İS VI. yüzyılda kilise ve martyrium mozaikleri içerisinde konu olarak, hayvan ve bitki figürlü cennet tasvirinin çok sık kullanıldığı gibi cennet tasvirlerinde de çeşitlilik görülmektedir. Samandă Matriyon Mozaiği (Campbell 1941: 43), Kırıkhan İncirli Köyü I Kilise Mozaiği (Çelik 2013: 4, 5), Arsuz Arpaçiftliği Kutsal Havariler Kilise Mozaiği’nde (Çelik 2018: 269,271,273) olduğu gibi cennet tasviri versiyonları birçok mozaik panoda 
kullanılmıştır. Hatay mozaiklerinde kullanılan cennet tasviri içerisinde, İncirli Köyü Martyrium Mozaiği’ne benzer göl tasviri bulunmadığı gibi dini mekân mozaikleri arasında, geometrik şablon içerisinde kuşlar düzenlemesi ayrıca ağaç önünde boğa düzenlemesi görülmemektedir. Bu durum Hatay'ın ortaya çıkarılan dini mekân mozaiklerinde kullanılan figürlerin benzer fakat kompozisyon olarak yorumlarının farklı olduğu sonucunu doğurmaktadır. Hatay'da ortaya çıkarılan dini mekânlardaki mozaiklerde kullanılan figür ve motiflerin çevresel etkilere göre yapıldığını, İncirli Köyü Martyrium Mozaiği’nde görmekteyiz. Martyrium'un bulunduğu İncirli Köyü'ne kuş uçuşu yaklaşık 7 km mesafede Aygır Gölü (Res. 38), yaklaşık 9 km mesafede ise Gölbaşı (Balıklı Göl) Gölü (Res. 39) bulunmaktadır. Mozaiklerde kullanılan gölde yaşayan balıklar, leylek, ördek ve nilüfer çiçekleri bu etkiyi kanıtlar niteliktedir. Yine İncirli Köyü I Kilise Mozaiği'nde (Çelik 2013: 4, 5, 6) kullanılan gazel, ördek, keçi gibi figürler bu çevresel etkiyi desteklemektedir. Fakat çevresel etkiyi Hatay'da bulunan dini mekân mozaiklerinin tamamı için kullanmak hatalı olacaktır. Dini mekânlardaki mozaiklerde kullanılan figürlere baktığımızda mozaik ustalarının elinde katalog olduğu ve figürleri bu katalogdan seçtikleri Hatay ve çevresinde yaşamayan hayvanların kullanılmasından anlaşılmaktadır.


Resim 39

Gölbaşı Gölü. 
Hatay'da bulunan sivil ve dini mekânlarda yapılan mozaik döşemelerindeki konu, kompozisyon, figür, motif ve bordürler incelendiğinde; İS II. yüzyıldan başlayan sanatsal süreç Antakya'da bulunan diğer Doğu Roma mozaiklerinde takp edildiği gibi, I. Iustinianus (İS 561) dönemine tarihlendirilen İncirli Köyü Mozaiği'nde de İS VI. yüzyıla kadar izlenilmektedir.

$\mathrm{Bu}$ durum Hatay'da mozaik ustalarının mozaik sanatındaki birikimlerininin yüzyıllarca kuşaktan kuşağa aktarıldığını gösterdiği gibi mozaik sanatındaki değişiklikleri ve yenilikleri de yansıtmaktadır.

\section{Kaynaklar - Bibliography}

Barsanti 2012

Campbell 1934

Campbell 1938a

Campbell 1938b

Campbell 1940

Çelik 2013

Çelik 2018

Décor I

Décor II

Downey 1973

Dunbabin 1999

Jones 1981

Kondoleon 2000

Lavin 1963

Levi 1945

Morey 1935

Morey 1938
C. Barsanti, "The Fate of the Antioch Mosaic Pavements: Some Reflection", JMR 5, 25-42.

W. A. Campbell, "Excavation at Antioch on the Orontes" AJA 38, 2, 201-206.

S. Campbell, The Mosaics of Antioch, Toronto.

W. A. Campbell, "The Fourth and Fifth Seasons of Excavation at Antioch-on-the-Orontes: 1935-1936", AJA 42, 2, 205-217.

W. A. Campbell, "The Sixth Season of Excavation at Antioch on the Orontes", AJA 44, 4, 417-427.

Ö. Çelik, “İncirli Köyü - I Mozaikleri”, JMR 6, 1-7.

Ö. Çelik, "Hatay, Arsuz, Kutsal Havariler Kilisesi”, 27. MKKS, 265-276.

C. Balmelle - M. Blanchard Lemée - J. Christophe - J.-P. Darmon - A.-M. Guimier Sorbets - H. Lavagne - R. Prudhomme - H. Stern, Le Décor géométrique de la mosaïque romaine I, Paris, 1985.

C. Balmelle - M. Blanchard-Lemée - J.- P. Darmon - S. Gozlan - M. P. Raynaud, Le Décor géométrique de la mosaïque romaine II, Paris, 2002.

G. Downey, Ancient Antioch, New Jersey.

K. M. D. Dunbabin, Mosaics of the Greek and Roman World, Cambridge.

F. F. Jones, “Antioch Mosaics in Princeton”, Record of the Art Museum, Princeton University, 40, 2, 2-26.

C. Kondoleon, Antioch The Lost Anciet City, New Jersey.

I. Lavin, "The Hunting Mosaics of Antiochand Their Sources. A Study of Compositional Principles in the Development of Early Mediaeval Style”, DOP 17, 179-286.

D. Levi, Antioch Mosaic Pavement, Volume I-II, Princeton.

C. R. Morey, "The Excavation of Antioch on the Orontes", Parnassus 7, 4, 9-12.

C. R. Morey, The Mosaics of Antioch, London. 
